\title{
CORONAVIRUS
}

\section{Robust immune responses are observed after one dose of BNT162b2 mRNA vaccine dose in SARS-CoV-2 experienced individuals}

\author{
Marie I. Samanovic ${ }^{1 \dagger}$, Amber R. Cornelius ${ }^{1+}$, Sophie L. Gray-Gaillard ${ }^{1}$, Joseph Richard Allen', Trishala

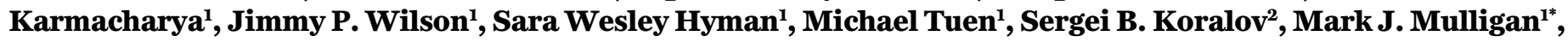 \\ Ramin Sedaghat Herati ${ }^{*}$
}

${ }^{1}$ NYU Langone Vaccine Center, Department of Medicine, New York University Grossman School of Medicine; New York, NY 10016, USA.

²Department of Pathology, New York University School of Medicine; New York, NY 10016, USA.

†These authors contributed equally to this work

*These authors contributed equally to this work.

${ }^{*}$ Corresponding authors: Ramin Sedaghat Herati, ramin.herati@nyulangone.org; Mark J. Mulligan, mark.mulligan@nyulangone.org

The use of COVID-19 vaccines will play the major role in helping to end the pandemic that has killed millions worldwide. COVID-19 vaccines have resulted in robust humoral responses and protective efficacy in human trials, but efficacy trials excluded individuals with a prior diagnosis of COVID-19. As a result, little is known about how immune responses induced by mRNA vaccines differ in individuals who recovered from COVID19. Here, we evaluated longitudinal immune responses to two-dose BNT162b2 mRNA vaccination in 15 adults who had experienced COVID-19, compared to 21 adults who did not have prior COVID-19. Consistent with prior studies of mRNA vaccines, we observed robust cytotoxic CD8 ${ }^{+} \mathrm{T}$ cell responses in both cohorts following the second dose. Furthermore, SARS-CoV-2-naive individuals had progressive increases in humoral and antigen-specific antibody-secreting cell (ASC) responses following each dose of vaccine, whereas SARS-CoV-2-experienced individuals demonstrated strong humoral and antigen-specific ASC responses to the first dose but these responses were not further enhanced after the second dose of the vaccine at the time points studied. Together, these data highlight the relevance of immunological history for understanding vaccine immune responses and may have implications for personalizing mRNA vaccination regimens used to prevent COVID-19, including for the deployment of booster shots.

\section{INTRODUCTION}

Severe acute respiratory syndrome coronavirus 2 (SARSCoV-2) has caused hundreds of millions of infections and millions of deaths worldwide (1). Although repeated infection has been described $(2,3)$, resolution of SARS-CoV-2 infection was associated with reduced susceptibility to re-infection in animal models (4) and in humans (5). However, it remains unknown how long this protection lasts. A number of promising vaccine candidates have emerged, including mRNA vaccines, vector-based vaccines, and protein-adjuvant vaccines (6). Maintenance of protective immune responses by vaccines will be important for preventing de novo and recurrent infection with SARS-CoV-2.

Identification of protective correlates of immunity will be critical to predicting susceptibility to SARS-CoV-2 infection. Humoral responses have been identified as a correlate of immunity for a variety of pathogens (7). In the setting of SARSCoV-2 infection in non-human primates, humoral responses conferred protection and $\mathrm{T}$ cell responses were partially protective in the setting of waning antibody titers (8). Indeed, studies with mRNA vaccine candidates against SARS-CoV-2 have induced robust humoral responses against SARS-CoV-2 in animal models (9-11) and in humans (12-17) and were efficacious in large-scale clinical trials $(18,19)$. In addition to humoral responses, mRNA vaccines induced type 1 responses in $\mathrm{CD}_{4}{ }^{+} \mathrm{T}$ cells, as evidenced by enzyme-linked immunospot (ELISpot) and intracellular cytokine staining for interferon (IFN)- $\gamma$ and tumor necrosis factor (TNF) $(13,14)$. Recent studies have highlighted antigen-specific B cell responses (20) and germinal center formation after mRNA vaccination (21). However, the full spectrum of immune responses to the vaccines has not been evaluated.

Memory is the hallmark of adaptive immune responses and typically results in faster response to the pathogen upon re-exposure. Immunological history can radically shape subsequent immune responses in other ways. For example, influenza susceptibility has been linked to strain-specific exposure from decades earlier $(22,23)$. Moreover, non-neutralizing 
antibody responses to acute dengue infection are a risk factor for antibody-dependent disease enhancement for serodiscordant strains $(24,25)$. These, and other examples from the literature (26), further highlight the importance for understanding immunological history in the context of coronavirus disease 2019 (COVID-19) vaccines. Moreover, large-scale clinical trials excluded individuals with a prior diagnosis of COVID-19, thereby leaving an unexplored gap in our understanding of vaccine responses in SARS-CoV-2-experienced individuals. Indeed, given the scope of the pandemic, addressing this gap in knowledge will be relevant to hundreds of millions of recovered individuals worldwide.

Here, our goal was to evaluate the effects of a prior history of COVID-19 on the immune response to mRNA vaccination. Following COVID-19, humoral and cellular immune responses persist (27-29), but little is known about the effects of prior COVID-19 on subsequent exposure to SARS-CoV-2 proteins. In an observational study, we longitudinally evaluated immune responses to mRNA vaccines in adults who were naive to SARS-CoV-2 (SARS-CoV-2-naive) or who had experienced SARS-CoV-2 infection (SARS-CoV-2experienced). Using unbiased high-dimensional flow cytometry analyses, we observed cytotoxic $\mathrm{CD} 8^{+} \mathrm{T}$ cell responses to vaccination in both cohorts. However, further analysis revealed subtle differences between cohorts. We found evidence for altered SARS-CoV-2-specific antibody-secreting cell (ASC) induction in circulation and altered humoral responses to vaccination depending on prior history of COVID-19. Better understanding of how prior COVID-19 shapes the immune responses to COVID-19 vaccines will improve our ability to predict susceptibility and enable personalized vaccine strategies for maintenance of immunity with booster shots.

\section{RESULTS}

\section{Robust $T$ cell responses are observed following mRNA vaccination.}

Prior immune history can affect subsequent responses to antigen (30). To test the effects of immunological history in the setting of COVID-19, we recruited 15 individuals who had laboratory-confirmed COVID-19 (hereafter labeled SARSCoV-2-experienced) and 21 individuals who did not have documented COVID-19 (hereafter labeled SARS-CoV-2-naive). Participants' ages ranged from 21 to 65, with a median age of 39 for naive adults and 43 for SARS-CoV-2-experienced individuals (table S1). All SARS-CoV-2-experienced adults had mild COVID-19 or asymptomatic infection except one individual who had severe disease (table S2). Two individuals were infected with SARS-CoV-2 within 30 days prior to vaccination, whereas the remaining 13 were at least eight months beyond diagnosis of COVID-19. For these two cohorts, all participants received two doses of the BNT162b2 mRNA vaccine in accordance with the FDA Emergency Use Authorization. Peripheral immune responses were assessed before and after each dose of vaccine (Fig. 1A). Relative to the start of vaccination, samples were categorized as Baseline, Post 1st dose (6 to 13 days after vaccination), Pre 2nd dose (immediately prior to second vaccination and about 21 days since initial vaccination), Post 2 nd dose (7 to 12 days after second vaccination), and One month post 2 nd dose (about 4 weeks after second vaccination) (Fig. 1A and fig. S1A). We opted to look at one week after second vaccination as that was the peak of the humoral response following mRNA vaccination $(12,16,31)$.

To determine the phenotype of circulating $\mathrm{T}$ cells responding to vaccination, we performed high-dimensional spectral flow cytometry longitudinally for all participants (fig. S1B and table S3). We initially reasoned that T cell responses would be most evident following the second dose, thus we performed cluster analysis (32) and $t$-distributed stochastic neighbor embedding (tSNE) representation of all non-naive $\mathrm{CD}^{+} \mathrm{T}$ cells pooled from all time points and all participants (Fig. 1B). Of the 29 clusters identified, only a single cluster (Cluster 12) increased in abundance at the Post 2nd dose time point compared to Pre 2nd dose (Fig. 1C and fig. S1C). Cells in Cluster 12 expressed multiple proteins that are associated with activation, including Ki67, CD38, and Inducible costimulator (ICOS) (Fig. 1D and fig. S1D). We next assessed these cells longitudinally using manual gating for Ki67 and CD38. Indeed, we found that vaccination was associated with robust induction of $\mathrm{Ki}^{2} 7^{+} \mathrm{CD} 38^{+} \mathrm{CD} 8^{+} \mathrm{T}$ cells one week after each vaccination (Fig. 1, E and $\mathbf{F}$ ), which was consistent with prior reports of robust induction of cytotoxic $\mathrm{T}$ cells after vaccination (33). Compared to baseline $\mathrm{Ki} 67^{+} \mathrm{CD} 38^{+}$ $\mathrm{CD}^{+} \mathrm{T}$ cell frequencies, the first vaccination induced a median 1.9-fold increase for SARS-CoV-2-naive and for SARSCoV-2-experienced individuals one week post first dose. However, compared with the Pre 2nd dose time point, the second vaccination induced a 2.2-fold and 3.3-fold increase in SARSCoV-2-naive and -experienced individuals, respectively, at one week post second dose. We also considered whether there might be differential timing of $\mathrm{CD}^{+} \mathrm{T}$ cell responses between the two cohorts, but analysis of time as a continuous variable did not identify a consistent pattern (fig. S1, E and F). Moreover, $\mathrm{Ki} 67^{+} \mathrm{CD} 38^{+} \mathrm{CD}^{+} \mathrm{T}$ cells expressed Granzyme B, suggesting strong cytotoxic potential, and responded with memory kinetics to repeat exposure to SARS-CoV-2 antigens (fig. S1, G and H). Together, these data show that mRNA vaccination was associated with cytotoxic $\mathrm{CD} 8^{+} \mathrm{T}$ cell responses in both cohorts.

We next asked if similar changes were evident in circulating $\mathrm{CD}^{+} \mathrm{T}$ cells. Here, cluster analysis of non-naive $\mathrm{CD} 4^{+} \mathrm{T}$ cells identified 22 clusters, two of which increased in abundance after the second dose of vaccine: Clusters 13 and 21 (fig. S1, I and J). Of these responding clusters, Cluster 13 was associated with high expression of Ki67, CD38, and ICOS (fig. 
$\mathrm{S} 1, \mathrm{~K}$ and $\mathrm{L}$ ). Indeed, longitudinal analysis revealed induction of $\mathrm{Ki} 67^{+} \mathrm{CD} 38^{+} \mathrm{CD} 4^{+} \mathrm{T}$ cells following immunization in the SARS-CoV-2-naive adults, with a 1.9-fold increase after first vaccination compared to baseline and a 1.3-fold increase at Post 2nd dose compared to Pre 2nd dose time points (Fig. 1, $\mathbf{G}$ and $\mathbf{H}$ ). In contrast, we observed muted $\mathrm{CD} 4^{+}$responses in SARS-CoV-2-experienced adults. We considered whether there might be differential timing of $\mathrm{CD}^{+} \mathrm{T}$ cell responses between the two cohorts but again did not identify a consistent pattern (fig. S1, M and N). Interestingly, the two participants with recent COVID-19 infection showed the strongest $\mathrm{CD}^{+} \mathrm{T}$ cell dynamic responses after each dose in the experienced cohort, whereas their $\mathrm{CD} 4^{+} \mathrm{T}$ cell response remained muted (fig. S1O). These data demonstrated induction of an activated $\mathrm{CD} 4^{+} \mathrm{T}$ cell population after vaccination in SARS-CoV-2-naive adults with only muted responses in SARS-CoV-2-experienced adults.

We next asked if these activated $\mathrm{CD} 4^{+}$and $\mathrm{CD} 8^{+} \mathrm{T}$ cell responses were correlated. Indeed, we found strong positive correlation between activated $\mathrm{CD} 4^{+}$and $\mathrm{CD} 8^{+}$responses after the first dose of vaccine and a weak correlation after the second dose of vaccine in SARS-CoV-2-naive adults (Fig. 1, I and J). In contrast, activated $\mathrm{CD} 4^{+}$and $\mathrm{CD}^{+}$responses in SARSCoV-2-experienced adults had only a modest correlation after the first dose and no correlation after the second dose of vaccine. We also considered other demographic variables in the analysis. Aging has been associated with reduced vaccine immunogenicity and effectiveness (34). Indeed, COVID-19 mortality increases with age (35), and it remains unclear how well COVID-19 vaccines perform in older adults (36). Here, we observed no correlation with age in activated $\mathrm{CD} 8^{+} \mathrm{T}$ cell responses. In contrast, we found negative correlations for activated $\mathrm{CD}_{4}{ }^{+} \mathrm{T}$ cell responses with participant age following both primary and second vaccinations (Fig. 1K and fig. $\mathrm{S} 1, \mathrm{P}$ and $\mathrm{Q}$ ). These results indicated the potential for reduced $\mathrm{CD}^{+} \mathrm{T}$ cell responses to vaccination with aging and underscored the need for additional studies to fully understand the effects of aging on mRNA vaccine-induced immune responses.

\section{Antigen-specific $T$ cell responses are induced by mRNA vaccination.}

We observed $\mathrm{T}$ cell responses based on phenotypic changes in both cohorts (Fig. 1), which led to the hypothesis that the vaccination had induced antigen-specific $\mathrm{T}$ cell responses. We first considered cytokine production following stimulation, as prior studies demonstrated the presence of TNF- or IFN- $\gamma$-producing T cells following mRNA immunization (14). We performed overnight stimulation of peripheral blood mononuclear cells (PBMCs) with peptide pools for the SARS-CoV-2 spike protein across all time points, followed by intracellular staining for IFN- $\gamma$ or TNF. Anti-spike protein T cell responses were observed at baseline (fig. S2, A to F), consistent with reports of pre-existing cross-reactivity (37). Following vaccination, we observed progressively higher frequencies of $\mathrm{CD} 8^{+}$and $\mathrm{CD} 4^{+} \mathrm{T}$ cells producing these cytokines in response to peptide stimulation among SARS-CoV-2-naive adults but stable frequencies of $\mathrm{CD}^{+}$and $\mathrm{CD} 4^{+} \mathrm{T}$ cells producing these cytokines among SARS-CoV-2-experienced adults. These data indicated that antigen-specific $\mathrm{T}$ cells were induced by vaccination in SARS-CoV-2-naive adults.

We next considered other means of identifying antigenspecific cells. We $(38)$ and others $(37,39,40)$ have demonstrated the use of activation-induced markers (AIM) as a method to study antigen-specific $\mathrm{T}$ cells that may not produce cytokines. Following overnight stimulation of PBMCs with peptide pools for the SARS-CoV-2 spike protein, we identified induction of $\mathrm{CD} 137^{+} \mathrm{IFN}-\gamma^{+} \mathrm{CD}^{+}$cells after vaccination in SARS-CoV-2-naive adults but not in SARS-CoV-2-experienced adults (Fig. 2, $\mathbf{A}$ and $\mathbf{B}$, and fig. S2G). We next considered $\mathrm{CD}^{+} \mathrm{T}$ cell induction by vaccination (Fig. $2, \mathbf{C}$ and $\mathbf{D}$, and fig. $\mathrm{S} 2 \mathrm{H}$ ). Similar to $\mathrm{CD}^{+} \mathrm{T}$ cell responses, $\mathrm{CD} 4^{+} \mathrm{T}$ cells coexpressing CD69 and CD200 after stimulation increased 9-fold at one month post second vaccination relative to baseline in SARS-CoV-2-naive adults $(P=0.025$, Kruskal-Wallis with Dunn's post-test) but did not increase in SARS-CoV-2experienced adults. We also considered other surface proteins including co-expression of OX40 and CD137 and observed similar results (fig. S2, I to L). In sum, spike proteinspecific $\mathrm{T}$ cell responses were induced in SARS-CoV-2-naive adults but did not further increase in SARS-CoV-2experienced adults after mRNA vaccination.

Differential induction of circulating $T$ follicular helper cells after vaccination was observed between those with and without prior history ofCOVID-19.

Most vaccines are thought to confer protection by induction of a class-switched, affinity-matured antibody response (7), and, given the subtle differences in $\mathrm{CD} 4^{+} \mathrm{T}$ cell responses following mRNA vaccination between cohorts (Fig. 1), we next considered $\mathrm{CD} 4{ }^{+} \mathrm{T}$ cell responses that might be relevant to the antibody response. Maturation of $\mathrm{B}$ cell responses within germinal centers requires help from $\mathrm{CD}_{4}^{+} \mathrm{T}$ follicular cells (Tfh) $(41,42)$. Indeed, spike protein-specific germinal center B cells were identified in axillary lymph node aspirates after mRNA vaccination (21). However, lymphoid tissue is challenging to routinely study in humans. We, and others, have focused on a circulating Tfh-like subset with similar phenotypic, transcriptional, epigenetic, and functional characteristics to lymphoid Tfh (43-47). Indeed, we previously found that vaccination induced antigen-specific $\mathrm{ICOS}^{+} \mathrm{CD} 38^{+}$ circulating Tfh (cTfh) which correlated with plasmablast responses and demonstrated memory kinetics (38). Furthermore, other studies identified similar activated cTfh responses in non-human primates following mRNA vaccination for influenza (48). However, activated cTfh have not 
been evaluated in humans following SARS-CoV-2 mRNA vaccination.

We scrutinized all time points for evidence of cTfh responses. ICOS ${ }^{+} \mathrm{CD} 38^{+}$cTfh cells increased following vaccination in SARS-CoV-2-naive adults and peaked one week after the second vaccine dose (Fig. 3, A and B). In contrast, SARSCoV-2-experienced adults did not show similar induction of cTfh cells following either dose of the vaccine (Fig. 3B). In prior studies, antigen-specific $\mathrm{ICOS}^{+} \mathrm{CD} 38^{+}$cTfh expressed CXCR3 following influenza vaccination $(38,46)$. Thus we next considered the subset of $\mathrm{ICOS}^{+} \mathrm{CD} 38^{+} \mathrm{cTfh}$ that expressed CXCR3. Here, we identified a 2.1-fold induction of CXCR3 ${ }^{+}$ cells among $\mathrm{ICOS}^{+} \mathrm{CD} 38^{+}$cTfh cells in SARS-CoV-2experienced adults after the first vaccine dose and a 2.0-fold increase among SARS-CoV-2-naive adults after the first dose (Fig. 3, $\mathbf{C}$ and D). There was minimal change in CXCR3 expression in $\mathrm{ICOS}^{+} \mathrm{CD} 38^{+}$cTfh one week after the second dose of vaccine in either cohort. Of note, SARS-CoV-2-experienced participants with recent COVID-19 showed a more dynamic induction of $\mathrm{CXCR} 3^{+}$cells among $\mathrm{ICOS}^{+} \mathrm{CD} 38^{+}$cTfh cells after each vaccine dose (fig. S3A).

We next used the AIM assay to identify antigen-specific cTfh induced by vaccination, as we have done previously (38). Spike protein-specific activated cTfh in the AIM assay were identified as $\mathrm{CD}^{+} \mathrm{T}$ cells expressing CXCR5 and programmed cell death protein 1 (PD-1) that had high expression of CD38 and that coexpressed CD69 and CD200 after overnight stimulation with a spike peptide pool (Fig. 3, E and F). In this subset, we found a 14.5-fold induction of cells that among SARS-CoV-2-naive adults at the Post 2nd dose time point relative to baseline $(P=0.008$, Kruskal-Wallis with Dunn's post-test), whereas no increase was observed among SARS-CoV-2-experienced adults during the same time interval (Fig. 3, E and F), which was similar to the trend observed for the CXCR $3^{+} \mathrm{ICOS}^{+} \mathrm{CD} 38^{+}$cTfh (Fig. 3, C and D). Together, these data demonstrated the induction of spike protein-specific cTfh in SARS-CoV-2-naive adults following mRNA vaccination.

Thus, we asked if the cTfh response correlated with the $\mathrm{Ki} 67^{+} \mathrm{CD} 38^{+} \mathrm{CD}_{4}^{+}$response. Indeed, $\mathrm{ICOS}^{+} \mathrm{CD} 38^{+}$cTfh from SARS-CoV-2-naive adults correlated positively with $\mathrm{Ki} 67^{+} \mathrm{CD} 38^{+} \mathrm{CD}^{+} \mathrm{T}$ cells for the fold-change at Post 1st dose compared to baseline (Fig. 3G and fig. S3B) and at Post 2nd dose compared to Pre 2nd dose (Fig. $\mathbf{3 H}$ and fig. S3C). In contrast, SARS-CoV-2-experienced adults had a positive correlation after the first dose and did not have a correlation after the second dose. We also found negative correlations with age in both cohorts (Fig. 3I), similar to what was observed for activated $\mathrm{CD}_{4}^{+}$responses (Fig. 1).

We also evaluated other well-established cellular correlates of the humoral response such as plasmablasts (48), CD2 ${ }^{1 \mathrm{lo}} \mathrm{B}$ cells (49), and CD71 $\mathrm{B}$ cells (50). However, we found little or no induction of these subsets in either cohort longitudinally (fig. S3, D to J). Plasma CXCL13, which has been reported as a plasma biomarker of early germinal center activity (51), also did not change following vaccination in either cohort (fig. S3, K and L).

Altogether, we found antigen-specific induction of $\mathrm{ICOS}^{+} \mathrm{CD} 38^{+}$cTfh following vaccination with subtle differences between cohorts. Indeed, although the $\mathrm{ICOS}^{+} \mathrm{CD} 38^{+}$ cTfh frequency continued to increase in the SARS-CoV-2naive adults there was no evidence of sustained induction of cTfh in SARS-CoV-2-experienced adults over the course of the vaccination series. Given that Tfh provide help to B cells, these data provoked the question as to whether B cell responses also differed by prior history of COVID-19.

Fewer SARS-CoV-2-specific ASCs are present in circulation after two vaccine doses in SARS-CoV-2experienced verus naïve adults.

We observed subtle differences in induction of $\mathrm{ICOS}^{+} \mathrm{CD} 38^{+} \mathrm{cTfh}$ following vaccination based on prior history of COVID-19 (Fig. 3). Thus, we next asked if antigen-specific $B$ cell responses induced by vaccination were influenced by prior exposure to the virus. To test this, we performed ELISpot analyses of ASCs for reactivity against SARS-CoV-2 proteins one week after each vaccine dose for both cohorts.

Given the persistence of SARS-CoV-2-reactive B cells in individuals who recovered from COVID-19 (28), we expected to find a stronger antigen-specific ASC response in SARS-CoV2-experienced adults than SARS-CoV-2-naive adults after the first dose of vaccine. Indeed, after the first dose of vaccine, SARS-CoV-2-naive adults had few SARS-CoV-2-specific ASCs detected, whereas SARS-CoV-2-experienced adults had stronger IgG-secreting ASC responses to the receptor binding domain (RBD), S1 domain, and S2 domain (Fig. 4, $\mathbf{A}$ to $\mathbf{C}$, fig. S4, A and B). Moreover, IgA-secreting ASCs were identified predominantly in SARS-CoV-2-experienced adults after the first vaccine dose, albeit at a somewhat lower frequency than IgG-secreting ASCs (Fig. 4D). Few IgM-secreting ASC were identified (fig. S4C). Although global plasmablast frequencies did not change with vaccination (fig. S3, D to F), we did indeed find evidence of antigen-specific ASCs responses following the first vaccine dose among both cohorts.

We next asked if the second vaccination also induced strong antigen-specific ASC responses in the two cohorts. Indeed, the second dose of vaccine robustly induced S1- and RBD-reactive ASCs in SARS-CoV-2-naive adults (Fig. 4, E to I and fig. S4D). In contrast, however, the second dose of vaccine induced similar, or weaker, ASC responses in SARS-COV2-experienced adults approximately one week after vaccination for all three SARS-CoV-2 antigens tested (Fig. 4, E to I and fig. S4D). Spike protein-specific ASC induction was correlated by isotype and antigen in SARS-CoV-2-experienced adults one week after the first vaccination and SARS-CoV-2- 
naive one week after the second vaccination (Fig. 4, J and $\mathbf{K}$, fig. S4, E to H). However, correlations by isotype and antigen were not observed in the SARS-CoV-2-experienced adults following the second vaccination. Furthermore, the pattern of these correlations changed between doses. For example, among SARS-CoV-2-naive adults, there was correlation between IgM-, IgA-, and IgG-secreting ASCs after the second vaccination but not after first vaccination, whereas similar correlations were observed in ASCs from SARS-CoV-2experienced adults after the first, but not after the second, vaccination. The lack of correlation may have been partly due to the low numbers of ASCs detected, but further studies will be needed to determine how unswitched and switched B cell populations respond in the settings of priming and recall responses. Together, these data demonstrated increased induction of antigen-specific ASC responses with repeated vaccination in SARS-CoV-2-naive adults, whereas fewer antigen-specific ASCs were observed in circulation with repeated vaccination in SARS-CoV-2-experienced adults.

Antigen-specific B cells are induced by vaccination.

To further study the induction of SARS-CoV-2-specific B cell responses after immunization, we used fluorescent recombinant RBD protein to identify RBD-reactive B cells in PBMCs (fig. S5A). We found RBD-reactive B cells were 2-fold higher at baseline among SARS-CoV-2-experienced adults compared to SARS-CoV-2-naive adults $(P=0.03$, Wilcoxon test) (fig. S5B). Furthermore, fewer RBD-reactive B cells were class-switched B cells in SARS-CoV-2-naive adults, as evidenced by expression of IgG, relative to SARS-CoV-2experienced adults $(P=0.02$, Wilcoxon test, fig. S5C). Following immunization, increased frequencies of $\mathrm{RBD}^{+} \mathrm{B}$ cells were observed in both cohorts (Fig. 5, A and B), with fold-changes of 2.9 and 4.8 in SARS-CoV-2-naive and SARS-CoV-2experienced adults, respectively, at Post 2nd dose relative to Baseline. Moreover, SARS-CoV-2-naive adults had progressively more IgG+ $\mathrm{RBD}^{+} \mathrm{B}$ cells at Post 2 nd dose than at Baseline ( $P=0.01$, Kruskal-Wallis with Dunn's post-test, Fig. 5, C and $\mathbf{D}$ ), whereas SARS-CoV-2-experienced adults had minimal change in the proportion of $\mathrm{IgG}^{+} \mathrm{RBD}^{+} \mathrm{B}$ cells at the same time points ( $P=0.24$, one-way ANOVA with Tukey's post-test).

We next considered plasmablast differentiation, which is likely to be necessary for durable humoral immunity. Indeed, plasma cells were identified in the bone marrow of adults following COVID-19 mRNA vaccination (52). Though we identified ASCs (Fig. 4), we did not identify $\mathrm{RBD}^{+} \mathrm{B}$ cells that had a $\mathrm{CD} 27^{+} \mathrm{CD} 38^{\text {hi }}$ phenotype, presumably due to down-regulation of the B cell receptor. However, other B cell subsets relevant to plasmablast differentiation were identified. For example, $\mathrm{CD} 71^{+} \mathrm{B}$ cells, which were described following influenza vaccination (50), were induced most strongly by the second immunization in SARS-CoV-2-naive adults but were induced most strongly by the first immunization in SARS-
CoV-2-experienced adults (Fig. 5, E and F, fig. S5D). Progressive $\mathrm{B}$ cell differentiation is associated with reduced expression of CD24 (53). Indeed, we found that some $\mathrm{RBD}^{+} \mathrm{B}$ cells had low expression of CD24 in both cohorts after vaccination (fig. S5, E and F). Similarly, B cells with low expression of CD21, which are thought to be precursors to long-lived plasma cells (49), were induced, albeit weakly, in the $\mathrm{RBD}^{+} \mathrm{B}$ cell subset after vaccination (fig. S5G). Double negative (DN) 2 B cells (54-56) were also increased in the $\mathrm{RBD}^{+} \mathrm{B}$ cell subset after immunization (fig. S5, H and I). Each of these populations could represent different populations of mixed activated $B$ cells and antibody secreting cells; nonetheless these data together indicated that $\mathrm{RBD}^{+} \mathrm{B}$ cells were induced by immunization and likely progressively developed phenotypes associated with differentiation.

\section{Humoral responses differ by history ofCOVID-19.}

ASC induction differed by prior history of COVID-19 (Fig. 4), thus we next asked whether humoral responses were affected by prior history of COVID-19. To test this, we first assessed antibody responses to the S1 subunit of the spike protein (57). As previously demonstrated (28), anti-S1 IgG antibodies were detectable in individuals who had recovered from COVID-19 and were not detectable in those who were SARS-CoV-2-naive at baseline (median titers 5991 and 25, respectively; $P=3.1 \times 10^{-8}$; Wilcoxon test) (Fig. 6A and fig. S6A). Following first dose immunization, SARS-CoV-2-experienced adults had a median fold-change of 92 whereas SARS-CoV-2naive adults had a median fold-change of only 2.7 $\left(P=6.9 \times 10^{-4}\right.$; Wilcoxon test). However, after second dose immunization, SARS-CoV-2-experienced adults had a median fold-change of only 1.3 whereas the SARS-CoV-2-naive adults had a fold-change of 11 ( $P=3.3 \times 10^{-5}$; Wilcoxon test). Compared to the SARS-CoV-2-naive cohort, the SARS-CoV-2experienced cohort had similar anti-S1 IgG titers at the Post 2nd dose time point but had 1.75-fold higher titers at One month post 2 nd dose $\left(P=5.3 \times 10^{-3}\right.$; Wilcoxon test, fig. S6B). However, no difference was observed between the Post 2nd dose and One month post 2nd dose time points for either cohort (paired $t$-test, Fig. 6A). An overall similar pattern was observed for anti-S1 IgA titers (Fig. 6B), and, as expected, vaccination did not affect anti-nucleocapsid antibodies (fig. S6, C and D). The change in anti-S1 IgG titer in SARS-CoV-2experienced adults was inversely correlated with their titer at baseline (fig. S6E). Thus, these data demonstrate rapid and robust humoral responses after initial vaccination in both cohorts but minimal further increase in SARS-CoV-2experienced adults after the second vaccine dose.

In a subset of participants, we asked if live-virus neutralizing antibodies were induced following immunization. We observed low titers of neutralizing antibodies at baseline in SARS-CoV-2-experienced adults, whereas plasma from SARSCoV-2-naive adults did not have detectable neutralizing 
antibodies (Fig. 6, C and D, fig. S6F). Following the first immunization, SARS-CoV-2-experienced adults had a rapid increase in neutralizing antibody titers to a median of 4084, whereas SARS-CoV-2-naive adults achieved a titer of 10 $\left(P=8.7 \times 10^{-5}\right.$; Wilcoxon test). As observed earlier with anti-S1 binding antibodies, subsequent neutralizing antibody titers were largely unchanged by second vaccination in SARS-CoV2-experienced adults, at least over the observed period, whereas the neutralizing titers in SARS-CoV-2-naive adults continued to increase. Nonetheless, neutralizing titers remained higher in the SARS-CoV-2-experienced adults compared to the SARS-CoV-2-naive adults at the Post 2nd dose time point (fig. S6G), and also at the One month post 2nd dose time point $\left(P=2.9 \times 10^{-3}\right.$, Wilcoxon test) (fig. S6H). We also considered whether participants with a recent COVID-19 diagnosis had any effect on vaccine responses compared to participants with more distant COVID-19 diagnosis but did not find clear effects (fig. S6 I to K). In sum, we found that neutralizing antibody responses induced by SARS-CoV-2 mRNA vaccination in SARS-CoV-2-experienced adults were of greater magnitude than in naive adults.

Antibody avidity has been used to assess affinity maturation following vaccination (58-60). To assess avidity, urea wash enzyme-linked immunosorbent assays (ELISAs) was performed for anti-S1 IgG antibodies on serum samples longitudinally. In SARS-CoV-2-naive adults, avidity continued to increase steadily over the measured time points (Fig. 6E), including at One month post 2 nd dose when antibody titers had plateaued. This prolonged period of increasing avidity is consistent with the recent report of human axillary lymph node germinal center reactions lasting at least 5 weeks post-RNA vaccination (21). All SARS-CoV-2-experienced adults assayed had relatively high-avidity antibodies at baseline, but, in contrast to SARS-CoV-2-naive adults, avidity decreased in four of five participants over time and with second vaccination, which may have been due to the induction of new, low avidity humoral responses that had not undergone germinal center maturation. All together, these data demonstrated pronounced differences in humoral responses based on prior history of COVID-19 (fig. S6L).

\section{DISCUSSION}

Prior studies have demonstrated the importance of humoral and cellular responses for susceptibility to COVID-19 (8). Better understanding of factors that affect immune responses will be critical to the design of next generation COVID-19 vaccines and their optimal use, including booster shots. Here, we observed subtle differences in cellular responses and more pronounced differences in humoral responses between individuals naive to SARS-CoV-2 and those who had recovered from SARS-CoV-2 infection. Both cohorts had similar $\mathrm{CD}^{+} \mathrm{T}$ cell responses to vaccination, which were typified by co-expression of Ki67 and CD38. In contrast, antigen-specific humoral cell responses differed by cohort. SARS-CoV-2-experienced adults had more antigen-specific ASCs in circulation one week after the first vaccination compared to SARS-CoV-2-naive adults, but the frequency of antigen-specific ASCs after second vaccination did not increase in previously infected individuals, unlike the SARS-CoV-2naive adults. In both cohorts, however, RBD-specific B cells increased in frequency in circulation following vaccination. Additionally, prior history of COVID-19 was associated with 100- to 1000-fold increase in anti-spike protein IgG antibody titers following the first vaccination, with limited increase upon the second vaccination; in contrast, antibody titers increased steadily over time in SARS-CoV-2-naive adults.

Prior studies demonstrated potent induction of $\mathrm{T}$ cell responses in animal models (33). Consistent with these studies, we also observed robust induction of cytotoxic $\mathrm{CD} 8^{+} \mathrm{T}$ cell responses following vaccination. The $\mathrm{Ki} 67^{+} \mathrm{CD} 38^{+} \mathrm{CD} 4^{+} \mathrm{T}$ cell responses we observed were consistent with other reports that have identified antigen-specific $\mathrm{CD}^{+} \mathrm{T}$ cell responses following mRNA vaccination (14). Moreover, we demonstrated the induction of spike protein-specific responses in both $\mathrm{CD} 8^{+}$and $\mathrm{CD} 4^{+} \mathrm{T}$ cells among SARS-CoV-2-naive adults using AIM. Although a robust $\mathrm{CD} 8{ }^{+} \mathrm{Ki} 67^{+} \mathrm{CD} 38^{+} \mathrm{T}$ cell response was observed phenotypically in PBMCs from SARSCoV-2-experienced adults, the AIM responses were low in magnitude. Further optimization of the peptide pools may be needed, as other studies have observed strong peptide-specific $\mathrm{CD}^{+}$responses. Additional studies of antigen specificity, such as by $\mathrm{T}$ cell tetramer assays, may help resolve $\mathrm{T}$ cell responses to individual epitopes. Future studies will be needed to determine whether spike protein-specific $\mathrm{T}$ cell responses after mRNA immunization in adults are a correlate of protection.

Durable, affinity-matured antibody responses require germinal center reactions in lymphoid tissue (42), and germinal centers are established following mRNA vaccination (21). Consistent with this, our spike protein antibody avidity experiments demonstrated progressive maturation of serum antibodies following mRNA vaccination, with increasing avidity through at least a month post second vaccination. However, much remains to be learned about $\mathrm{T} f \mathrm{fh}$ responses in this context and whether these cells play a role in antibody responses after mRNA vaccination (61). Two prior studies evaluated mRNA vaccination for influenza in humans and non-human primates and found robust induction of ICOS ${ }^{+} \mathrm{CXCR} 3^{+} \mathrm{PD}-1^{+}$cTfh responses and neutralizing antibodies $(48,62)$. Here, $\mathrm{CXCR}^{+} \mathrm{ICOS}^{+} \mathrm{CD} 38^{+}$cTfh were induced by vaccination in both cohorts. Furthermore, we previously demonstrated that antigen-specific cTfh responses were induced by influenza vaccination which correlated with cellular and humoral responses to vaccination $(38,63)$. Here as well, we found that mRNA vaccination induced spike protein- 
specific activated cTfh. However, activated cTfh are, at best, a proxy for understanding lymphoid Tfh responses in humans $(43,63)$. Plasma CXCL13, which increased after yellow fever vaccination, but not influenza vaccination $(51,64)$, was not different following mRNA vaccination in our study, which may indicate relative differences in extent of germinal center formation or perhaps differences in early germinal center events that lead to CXCL13 production. Additional studies involving direct lymph node sampling, as was done recently $(65,66)$, will be needed to understand Tfh dynamics and memory formation, and additional time points will be needed to determine the utility of cellular and humoral biomarkers, including plasma CXCL13 and the plasmablast response, following mRNA vaccination.

Notable qualitative and quantitative differences in immune responses were observed when comparing adults who were naive to SARS-CoV-2 to those who had recovered from SARS-CoV-2 infection. Anti-S1 binding IgG antibodies and neutralizing antibodies appeared to peak one week after second vaccination, consistent with published reports of humoral responses to mRNA vaccination $(12,18)$. By the end of the observation period, SARS-CoV-2-experienced adults had higher titers of anti-S1 binding IgG and neutralizing antibodies at the One month post 2nd dose time point, compared to SARS-CoV-2-naive adults. Moreover, humoral responses continued to qualitatively change in avidity for spike protein, despite the plateau in antibody quantity. In SARS-CoV-2-naive adults, affinity increased over time, which may reflect germinal center-related affinity maturation $(11,67)$. In contrast, SARS-CoV-2-experienced adults had reduction in affinity over time, presumably reflecting the contribution of de novo B cell responses that had not undergone affinity maturation, rather than loss of high-affinity antibodies. Indeed, better understanding the qualitative and quantitative changes in antibodies over time will have major implications for the need for booster vaccinations.

Furthermore, humoral responses were robust after the first vaccination but more muted after the second vaccination in SARS-CoV-2-experienced adults, and this pattern was also evident in anti-S1 IgG and anti-S1 IgA antibodies, as well as live-virus neutralizing antibodies. Several possibilities may explain these differences. For example, the early plateau in humoral responses could indicate altered B cell differentiation away from antigen-specific plasma cells, which would be consistent with the reduced ASC responses in SARS-CoV-2experienced adults after the second dose. In addition, the reduction in antigen-specific ASCs may have also altered trafficking of ASCs following repeat vaccination, perhaps shifting the peak ASC response earlier than was assessed here. Another possibility is that the very high titers of anti-S1 IgG responses may restrict antigen availability for stimulation of non-memory B cell clones following subsequent vaccine doses. Indeed, there was a strong negative correlation between the baseline anti-S1 IgG titer and the fold-change in anti-S1 IgG titers after first vaccination. Furthermore, differences between cohorts could arise from other differences prior to lymphocyte activation, such as during antigen-presenting cell priming, as the duration of the dysregulation of innate immune responses in the setting of COVID-19 remains unknown (68). Although there are diseases associated with the toxic accumulation of antibodies (such as light chain amyloidosis, nephrotoxicity due to multiple myeloma, and others), we are unaware of reports of these phenomena after immunization but may represent a theoretical risk. There are many other characteristics of the humoral response, such as neutralization capability, isotype, subclass, glycosylation pattern, and breadth of binding, which are likely to affect protection afforded by COVID-19 vaccines. In addition, it is unknown whether booster doses will lead to higher titers of antibodies or if they will only increase to some threshold, akin to minimal increase in titer that was observed with the second vaccination in SARS-CoV-2-experienced adults in our studies.

Although we observed differential induction of cellular and humoral responses to vaccination based on prior exposure to SARS-CoV-2, certain caveats apply to these studies. First, overall sample size was limited and thus our findings will need to be further validated in larger, diverse cohorts. Second, we tested BNT162b2 but were not able to test the many other COVID-19 vaccines being developed, nor did we assess later time points to determine longevity of the immune response. Furthermore, we opted to look one week after each vaccination based on prior influenza studies but cannot rule out that the timing of the peak cellular response occurred outside of the time points assessed. Future studies with blood draws shortly after vaccination, particularly after the second dose, may clarify whether a plasmablast response occurred. In addition, understanding the impact of pre-existing $\mathrm{T}$ and B cell memory due to seasonal coronaviruses on the magnitude of the COVID-19 vaccine response could improve the ability to predict the overall vaccine response. Finally, studies of the draining lymph node after vaccination may be needed to understand mechanisms underlying the differential responses observed here.

Together, these results highlight the importance of understanding prior immunological experience on the subsequent immune response to COVID-19 mRNA vaccines. Future studies will be needed to determine whether such personalized vaccination regimens will deliver durable, protective immunity to infection by the SARS-CoV-2 virus. Our results provide insight into the establishment and breadth of memory immune responses following mRNA vaccination. 


\section{MATERIALS AND METHODS}

\section{Study Design}

We conducted an observational study of adults who were receiving BNT162b2 vaccination and willing to participate in the study, excluding individuals with severe anemia or inability to comply with study procedures. Thirty-six adults (21 SARS-CoV-2-naïve and 15 SARS-CoV-2-experienced) provided written consent for enrollment with approval from the NYU Institutional Review Board (protocols 18-02035 and 1802037). Participants had blood drawn at defined time points, as diagrammed in Fig. 1A. Participant characteristics are summarized in Tables S1 and S2. Participant-level data are presented in data file S1. Sample size calculations were not performed prior to the start of this non-randomized, non-interventional study. Outlier analyses were not performed.

\section{Blood samples processing and storage}

Venous blood was collected by standard phlebotomy. Blood collection occurred at baseline, approximately one week after first vaccination ("Post 1st dose"), prior to the second vaccination ("Pre 2nd dose"), approximately one week after the second vaccination ("Post 2nd dose"), and one month after the second vaccination ("One month post 2 nd dose"), as depicted in Fig. 1A. PBMCs were isolated from heparin vacutainers (BD Biosciences) that were stored overnight at room temperature, followed by processing using Sepmates (STEMCELL Technologies) in accordance with the manufacturer's recommendations. Serum was collected in SST tubes (BD Biosciences) and frozen immediately at $-80^{\circ} \mathrm{C}$.

\section{Antibody ELISA and CXCL13 concentration evalua- tion}

Direct ELISA was used to quantify antibody titers in participant serum. Ninety-six well plates were coated with 1 $\mu \mathrm{g} / \mathrm{mL} \mathrm{S1}$ protein $(100 \mu \mathrm{L} /$ well $)$ or $0.1 \mu \mathrm{g} / \mathrm{mL} \mathrm{N}$ protein diluted in phosphate-buffered saline (PBS) and were then incubated overnight at $4{ }^{\circ} \mathrm{C}$ (Sino Biological Inc., 40591-V08H and 40588-V08B). Plates were washed four times with $250 \mu \mathrm{L}$ of PBS containing 0.05\% Tween 20 (Thermo Fisher Scientific) (PBS-T) and blocked with $200 \mu \mathrm{l}$ PBS-T containing $4 \%$ nonfat milk and 5\% whey, as blocking buffer at room temperature for 1 hour. Serum samples were heated at $56^{\circ} \mathrm{C}$ for 1 hour prior to use. Samples were diluted to a starting concentration of 1:50 (S1), or 1:100 (N) were first added to the plates and then serially diluted 1:3 in blocking solution. The final volume in all wells after dilution was $100 \mu \mathrm{L}$. After a 2-hour incubation period at room temperature, plates were washed four times with PBS-T. Horseradish peroxidase (HRP)conjugated goat-anti human IgG, IgM, and IgA (Southern BioTech, 2040-05, 2020-05, 2050-05) were diluted in blocking buffer (1:2000, 1:1000, 1:1000, respectively) and $100 \mu \mathrm{L}$ was added to each well. Plates were incubated for 1 hour at room temperature and washed four times with PBS-T. After developing for 5 min with TMB Peroxidase Substrate $3,3^{\prime}, 5,5^{\prime}$ -
Tetramethylbenzidine (Thermo Fisher Scientific), the reaction was stopped with $1 \mathrm{M}$ sulfuric acid or $1 \mathrm{~N}$ hydrochloric acid. The optical density was determined by measuring the absorbance at $450 \mathrm{~nm}$ on a Synergy 4 (BioTek) plate reader. To summarize data collected on individuals, the area under the response curve was calculated for each sample and end point titers were normalized using replicates of pooled positive control serum samples on each plate to reduce variability between plates. Measurement of CXCL13 concentrations was performed using plasma samples that had been stored at $80^{\circ} \mathrm{C}$. Plasma was warmed to room temperature and immediately diluted 1:1 in buffer. Diluted plasma was placed into a CXCL13 Simple Plex Cartridge (ProteinSimple, SPCKB-PS000375) according to the manufacturer's instructions.

\section{Avidity assay}

Ninety-six well plates were coated with $0.1 \mu \mathrm{g} / \mathrm{mL}$ S1 protein $(100 \mu \mathrm{L} /$ well $)$ diluted in PBS overnight at $4^{\circ} \mathrm{C}$ (Sino Biological). Plates were washed four times with $250 \mu \mathrm{L}$ of PBS containing $0.05 \%$ Tween 20 (PBS-T) and blocked with $200 \mu \mathrm{L}$ PBS-T containing $4 \%$ non-fat milk and $5 \%$ whey, as blocking buffer at room temperature for 1 hour. Serum samples were heated at $56^{\circ} \mathrm{C}$ for 1 hour prior to use. Samples were diluted to a starting concentration of 1:50 and added to the plates in quadruplicate and then serially diluted 1:3 in blocking solution. The final volume in all wells after dilution was $100 \mu \mathrm{L}$. After a 2-hour incubation period at room temperature, plates were washed four times with PBS-T. PBS was then added to two dilution replicate sets and $6 \mathrm{M}$ Urea to the other two dilution replicate sets. Plates were incubated for $10 \mathrm{~min}$ at room temperature before washing four times with PBS-T. Antibodies were detected and plates were developed and read as described above for ELISA assays. Avidity was calculated by dividing the dilutions that gave an optical density value of 0.5 (Urea treatment/no Urea). Scores with theoretical values between 0 and $100 \%$ were generated.

\section{Antibody-secreting cell ELISpot Assays}

A direct enzyme-linked immunospot (ELISpot) assay was used to determine the number of SARS-CoV-2 spike protein subunit S1-, S2-, and RBD-specific IgG, IgA, and IgM ASCs in fresh PBMCs. Ninety-six well ELISpot filter plates (Millipore, MSHAN4B50) were coated overnight with $2 \mu \mathrm{g} / \mathrm{mL}$ recombinant S1, S2, or RBD (Sino Biological Inc., 40591-V08H, 40590$\mathrm{V08B}$, and $40592-\mathrm{V08H})$, or $10 \mu \mathrm{g} / \mathrm{mL}$ of goat anti-human IgG/A/M capture antibody (Jackson ImmunoResearch Laboratory Inc., 109-005-064). Plates were washed four times with $200 \mu \mathrm{L}$ PBS-T and blocked for 2 hours at $37^{\circ} \mathrm{C}$ with 200 $\mu \mathrm{L}$ RPMI-1640 containing 10\% fetal calf serum (FCS), 100 units $/ \mathrm{mL}$ of penicillin $\mathrm{G}$, and $100 \mu \mathrm{g} / \mathrm{mL}$ of streptomycin (Gibco), referred to as complete medium. Then $50 \mu \mathrm{L}$ of cells in complete media at $10 \times 10^{6}$ cells $/ \mathrm{mL}$ were added to the top row of wells containing $150 \mu \mathrm{L}$ complete media and 3-fold serial diluted three times. Plates were incubated overnight at 
$37^{\circ} \mathrm{C}$ with $5 \% \mathrm{CO}_{2}$. Plates were washed once with $200 \mu \mathrm{L}$ PBS followed by four times with $200 \mu \mathrm{L}$ PBS containing $0.05 \%$ Tween 20 (PBS-T). Biotinylated anti-human IgG, IgM, or IgA antibody (Jackson ImmunoResearch Laboratory Inc., 709065-098, 109-065-129, 109-065-011) were diluted 1:1000 in PBS-T with $2 \%$ FCS (Ab diluent) and $100 \mu \mathrm{L}$ was added to wells for 2 hours at room temperature or overnight at $4^{\circ} \mathrm{C}$. Plates were washed four times with $200 \mu \mathrm{L}$ PBS-T and incubated with $100 \mu \mathrm{L}$ of Avidin-D-HRP conjugate (Vector Laboratories, A-2004) diluted 1:1000 in PBS-T for 1 hour at room temperature. Plates were washed four times with $200 \mu \mathrm{L}$ PBS$\mathrm{T}$ and $100 \mathrm{~mL}$ of AEC substrate (3 amino-9 ethyl-carbazole; Sigma Aldrich, A-5754) was added. Plates were incubated at room temperature for five minutes and rinsed with water to stop the reaction. Developed plates were scanned and analyzed using an ImmunoSpot automated ELISpot counter (Cellular Technology Limited).

\section{SARS-COV-2 microneutralization assay}

Viral neutralization activity of plasma was measured in an immunofluorescence-based microneutralization assay by detecting the neutralization of infectious virus in cultured Vero E6 cells (African Green Monkey Kidney; ATCC \#CRL-1586). These cells are known to be highly susceptible to infection by SARS-CoV-2. Cells were maintained according to standard ATCC protocols. Briefly, Vero E6 cells were grown in Dulbecco's Modified Eagle Medium (DMEM) supplemented with $10 \%$ heat-inactivated fetal bovine serum (FBS), $2 \mathrm{mM} \mathrm{L-glu-}$ tamine, and 1\% of MEM Nonessential Amino Acid (NEAA) Solution (Thermo Fisher Scientific, \#MT25025CI). Cell cultures were grown in 75 or $150 \mathrm{~cm}^{2}$ flasks at $37^{\circ} \mathrm{C}$ with $5 \% \mathrm{CO}_{2}$ and passaged 2 to 3 times per week using trypsin-EDTA. Cell cultures used for virus testing were prepared as subconfluent monolayers. All incubations containing cells were performed at $37^{\circ} \mathrm{C}$ with $5 \% \mathrm{CO}_{2}$. All SARS-CoV-2 infection assays were performed in the CDC/USDA-approved BSL3 facility of NYU Grossman School of Medicine, in accordance with its Biosafety Manual and Standard Operating Procedures. SARSCoV-2 isolate USA-WA1/2020, deposited by the Centers for Disease Control and Prevention, was obtained through Biodefense and Emerging Infections Research Resources Repository, National Institute of Allergy and Infectious Diseases, National Institutes of Health (NR-52281, GenBank accession no. MT233526). Serial dilutions of heat-inactivated plasma $\left(56^{\circ} \mathrm{C}\right.$ for 1 hour) were incubated with USA-WA1/2020 stock (at fixed $1 \times 10^{6} \mathrm{PFU} / \mathrm{mL}$ ) in DMEM supplemented with $2 \mathrm{mM}$ L-glutamine, 1\% of MEM Nonessential Amino Acid (NEAA) Solution, and $10 \mathrm{mM}$ HEPES (Thermo Fisher Scientific 15630-080) for 1 hour at $37^{\circ} \mathrm{C}$. One hundred microliters of the plasma-virus mix was then added to the cells and incubated at $37^{\circ} \mathrm{C}$ with $5 \% \mathrm{CO}_{2}$. Twenty-four hours post-infection, cells were fixed with $10 \%$ formalin solution ( $4 \%$ active formaldehyde) for 1 hour, stained with an $\alpha$-SARS-CoV-2 nucleocapsid antibody at 1:2,000 (ProSci \#10-605, RRID AB_2895130), and a goat $\alpha$-mouse IgG alexa fluor 647 secondary antibody at 1:2,000 (Thermo Fisher Scientific A32728, RRID AB_2633277) along with $4^{\prime}, 6$-diamidino-2-phenylindole (DAPI) at 1:4,000 and visualized by microscopy with the CellInsight CX7 HighContent Screening (HCS) Platform (Thermo Fisher Scientific) and high-content software (HCS) (69).

\section{Cellular phenotyping}

Peripheral blood was collected in sodium heparin collection tubes and maintained at room temperature overnight. PBMCs were isolated using the Sepmate system (STEMCELL Technologies) in accordance with manufacturer's instructions. Then, 2 to 5 million freshly isolated PBMCs were resuspended in HBSS supplemented with 1\% FCS (Thermo Fisher Scientific) and $0.02 \%$ sodium azide (Sigma-Aldrich). Cells underwent Fc-blockade with Human TruStain FcX (BioLegend) and NovaBlock (Thermo Fisher Scientific) for 10 min at room temperature, followed by surface staining antibody cocktail at room temperature for $20 \mathrm{~min}$ in the dark. Cells were permeabilized with the eBioscience Intracellular Fixation and Permeabilization kit (Thermo Fisher Scientific) for 20 min at room temperature in the dark, followed by intracellular staining with an antibody cocktail for 1 hour at room temperature in the dark. All samples were then resuspended in $1 \%$ paraformaldehyde and acquired within three days of staining on a 5-laser Aurora cytometer (Cytek Biosciences). Antibodies, clones, and catalog numbers are described in table S3. Initial data quality control was performed using FlowJo (BD Biosciences). Non-naive $\mathrm{CD}^{+}$and $\mathrm{CD} 4^{+} \mathrm{T}$ cells were analyzed in the OMIQ.ai platform (www.omiq.ai) using Phenograph clustering (32) with $\mathrm{k}=20$ and a Euclidean distance metric, followed by tSNE projection. Heatmaps and differential cluster abundance were assessed by edgeR (70) using OMIQ.ai.

\section{Activation-induced marker analysis}

Cryopreserved PBMCs were thawed and rested overnight at $37^{\circ} \mathrm{C}$ in RPMI-1640 with L-glutamine (Thermo Fisher Scientific) containing 10\% FCS (Thermo Fisher Scientific), $2 \mathrm{mM}$ L-glutamine (Thermo Fisher Scientific), and $100 \mathrm{U} / \mathrm{ml}$ of penicillin-streptomycin (Thermo Fisher Scientific). The following day, cells were stimulated with $0.6 \mathrm{nmol}$ of each of the S1, S, and S+ PepTivator pools (Miltenyi) for 20 hours at $37^{\circ} \mathrm{C}$ with $1.5 \times 10^{6}$ cells per well in a 96 well flat bottom plate. For the unstimulated control well, sterile water was used in place of the peptide pools. Monensin (Thermo Fisher Scientific) was added for the last 6 hours of stimulation at a final concentration of $10 \mu \mathrm{M}$. After stimulation, cells were washed with PBS containing $10 \mathrm{mM}$ EDTA at $37^{\circ} \mathrm{C}$ for $5 \mathrm{~min}$, followed by Fcblockade and were stained as previously described. Antibodies, clones, and catalog numbers are described in table $\mathbf{S 3}$. Analysis was performed using FlowJo.

\section{B cell tetramer assays}

Recombinant biotinylated RBD (BioLegend) was reacted 
with PE-Streptavidin (BioLegend) in a 4:1 molar ratio at $4{ }^{\circ} \mathrm{C}$ for 2 hours. For flow cytometry studies, PBMCs underwent Fc-blockade with Human TruStain FcX (BioLegend), NovaBlock (Thermo Fisher Scientific), APC-Streptavidin (BioLegend), and mouse phycoerythrin (PE)-IgG2b isotype control (BioLegend) for $10 \mathrm{~min}$ at room temperature, followed by allophycocyanin (APC) anti-PE (BioLegend) for 10 min. Then cells were washed twice and stained with the RBD tetramer and antibodies against other surface proteins for 20 min at room temperature in the dark, followed by resuspension in 1\% paraformaldehyde and acquisition on a 5-laser Aurora cytometer (Cytek Biosciences).

\section{Statistical analysis}

Primary data analysis and statistical analysis were performed using the R environment (version 4.0.2). Bioinformatics analysis scripts are available online at Zenodo (doi: 10.5281/zenodo.5731495). All experiments were performed once using the number of biological replicates indicated in the figure legends. Statistical tests were performed using the "rstatix" library (version 0.6.0) and conducted as two-tailed tests with $\alpha=0.05$. Nonparametric 2-sample Wilcoxon tests were performed preferentially throughout. Non-parametric Kruskal-Wallis test was used with Dunn's post-test in settings with 3 or more comparisons. Correlation analyses were performed as nonparametric tests using Kendall's tau statistic. Study schematics were made with BioRender.

\section{SUPPLEMENTARY MATERIALS}

www.science.org/doi/10.1126/scitranslmed.abi8961

Figs. S1 to 66

Tables S1 to S3

Reference (71)

Data file S1

MDAR Reproducibility Checklist

\section{REFERENCES AND NOTES}

1. E. Dong, H. Du, L. Gardner, An interactive web-based dashboard to track COVID-19 in real time. Lancet Infect. Dis. 20, 533-534 (2020). doi:10.1016/S14733099(20)30120-1 Medline

2. K. K.-W. To, I. F.-N. Hung, J. D. Ip, A. W.-H. Chu, W.-M. Chan, A. R. Tam, C. H.-Y. Fong, S. Yuan, H.-W. Tsoi, A. C.-K. Ng, L. L.-Y. Lee, P. Wan, E. Tso, W.-K. To, D. Tsang, K.H. Chan, J.-D. Huang, K.-H. Kok, V. C.-C. Cheng, K.-Y. Yuen, COVID-19 re-infection by a phylogenetically distinct SARS-coronavirus-2 strain confirmed by whole genome sequencing. Clin. Infect. Dis. (2020). doi:10.1093/cid/ciaa1275

3. R. Tillett, J. Sevinsky, P. Hartley, H. Kerwin, N. Crawford, A. Gorzalski, C. Laverdure, S. Verma, C. Rossetto, D. Jackson, M. Farrell, S. Van Hooser, M. Pandori, Genomic Evidence for a Case of Reinfection with SARS-CoV 2. SSRN Electronic Journal (2020). doi:10.2139/ssm.3680955 Medline

4. A. Chandrashekar, J. Liu, A. J. Martinot, K. McMahan, N. B. Mercado, L. Peter, L. H. Tostanoski, J. Yu, Z. Maliga, M. Nekorchuk, K. Busman-Sahay, M. Terry, L. M. Wrijil, S. Ducat, D. R. Martinez, C. Atyeo, S. Fischinger, J. S. Burke, M. D. Slein, L. Pessaint, A. Van Ry, J. Greenhouse, T. Taylor, K. Blade, A. Cook, B. Finneyfrock, R. Brown, E. Teow, J. Velasco, R. Zahn, F. Wegmann, P. Abbink, E. A. Bondzie, G. Dagotto, M. S. Gebre, X. He, C. Jacob-Dolan, N. Kordana, Z. Li, M. A. Lifton, S. H. Mahrokhian, L. F. Maxfield, R. Nityanandam, J. P. Nkolola, A. G. Schmidt, A. D. Miller, R. S. Baric, G. Alter, P. K. Sorger, J. D. Estes, H. Andersen, M. G. Lewis, D. H. Barouch, SARS-CoV-2 infection protects against rechallenge in rhesus macaques. Science 369, 812-817 (2020). doi:10.1126/science.abc4776 Medline

5. V. J. Hall, S. Foulkes, A. Charlett, A. Atti, E. J. M. Monk, R. Simmons, E. Wellington,
M. J. Cole, A. Saei, B. Oguti, K. Munro, S. Wallace, P. D. Kirwan, M. Shrotri, A. Vusirikala, S. Rokadiya, M. Kall, M. Zambon, M. Ramsay, T. Brooks, C. S. Brown, M. A. Chand, S. Hopkins; SIREN Study Group, SARS-CoV-2 infection rates of antibody-positive compared with antibody-negative health-care workers in England: A large, multicentre, prospective cohort study (SIREN). Lancet 397, 1459-1469 (2021). doi:10.1016/S0140-6736(21)00675-9 Medline

6. G. Forni, A. Mantovani; COVID-19 Commission of Accademia Nazionale dei Lincei, Rome, COVID-19 vaccines: Where we stand and challenges ahead. Cell Death Differ. 28, 626-639 (2021). doi:10.1038/s41418-020-00720-9 Medline

7. S. A. Plotkin, Correlates of protection induced by vaccination. Clin. Vaccine Immunol. 17, 1055-1065 (2010). doi:10.1128/CVI.00131-10 Medline

8. K. McMahan, J. Yu, N. B. Mercado, C. Loos, L. H. Tostanoski, A. Chandrashekar, J. Liu, L. Peter, C. Atyeo, A. Zhu, E. A. Bondzie, G. Dagotto, M. S. Gebre, C. JacobDolan, Z. Li, F. Nampanya, S. Patel, L. Pessaint, A. Van Ry, K. Blade, J. YalleyOgunro, M. Cabus, R. Brown, A. Cook, E. Teow, H. Andersen, M. G. Lewis, D. A. Lauffenburger, G. Alter, D. H. Barouch, Correlates of protection against SARSCoV-2 in rhesus macaques. Nature 590, 630-634 (2021). doi:10.1038/s41586020-03041-6 Medline

9. K. S. Corbett, B. Flynn, K. E. Foulds, J. R. Francica, S. Boyoglu-Barnum, A. P. Werner, B. Flach, S. O'Connell, K. W. Bock, M. Minai, B. M. Nagata, H. Andersen, D. R. Martinez, A. T. Noe, N. Douek, M. M. Donaldson, N. N. Nji, G. S. Alvarado, D. K. Edwards, D. R. Flebbe, E. Lamb, N. A. Doria-Rose, B. C. Lin, M. K. Louder, S. O'Dell, S. D. Schmidt, E. Phung, L. A. Chang, C. Yap, J. M. Todd, L. Pessaint, A. Van Ry, S. Browne, J. Greenhouse, T. Putman-Taylor, A. Strasbaugh, T. A. Campbell, A. Cook, A. Dodson, K. Steingrebe, W. Shi, Y. Zhang, O. M. Abiona, L. Wang, A. Pegu, E. S. Yang, K. Leung, T. Zhou, I. T. Teng, A. Widge, I. Gordon, L. Novik, R. A. Gillespie, R. J. Loomis, J. I. Moliva, G. Stewart-Jones, S. Himansu, W. P. Kong, M. C. Nason, K. M. Morabito, T. J. Ruckwardt, J. E. Ledgerwood, M. R. Gaudinski, P. D. Kwong, J. R. Mascola, A. Carfi, M. G. Lewis, R. S. Baric, A. McDermott, I. N. Moore, N. J. Sullivan, M. Roederer, R. A. Seder, B. S. Graham, Evaluation of the mRNA-1273 Vaccine against SARS-CoV-2 in Nonhuman Primates. N. Engl. J. Med. 383, 1544-1555 (2020). doi:10.1056/NEJMoa2024671 Medline

10. P. J. Klasse, D. F. Nixon, J. P. Moore, Immunogenicity of clinically relevant SARSCoV-2 vaccines in nonhuman primates and humans. Sci. Adv. 7, eabe8065 (2021) doi:10.1126/sciadv.abe8065 Medline

11. D. Laczkó, M. J. Hogan, S. A. Toulmin, P. Hicks, K. Lederer, B. T. Gaudette, D. Castaño, F. Amanat, H. Muramatsu, T. H. Oguin 3rd, A. Ojha, L. Zhang, Z. Mu, R. Parks, T. B. Manzoni, B. Roper, S. Strohmeier, I. Tombácz, L. Arwood, R. Nachbagauer, K. Karikó, J. Greenhouse, L. Pessaint, M. Porto, T. Putman-Taylor, A. Strasbaugh, T.-A. Campbell, P. J. C. Lin, Y. K. Tam, G. D. Sempowski, M. Farzan, H. Choe, K. O. Saunders, B. F. Haynes, H. Andersen, L. C. Eisenlohr, D. Weissman, F. Krammer, P. Bates, D. Allman, M. Locci, N. Pardi, A Single Immunization with Nucleoside-Modified mRNA Vaccines Elicits Strong Cellular and Humoral Immune Responses against SARS-CoV-2 in Mice. Immunity 53, 724-732.e7 (2020). doi:10.1016/i.immuni.2020.07.019 Medline

12. M. J. Mulligan, K. E. Lyke, N. Kitchin, J. Absalon, A. Gurtman, S. Lockhart, K. Neuzil, V. Raabe, R. Bailey, K. A. Swanson, P. Li, K. Koury, W. Kalina, D. Cooper, C. FontesGarfias, P.-Y. Shi, Ö. Türeci, K. R. Tompkins, E. E. Walsh, R. Frenck, A. R. Falsey, P. R. Dormitzer, W. C. Gruber, U. Şahin, K. U. Jansen, Phase I/II study of COVID-19 RNA vaccine BNT162b1 in adults. Nature 586, 589-593 (2020). doi:10.1038/s41586-020-2639-4 Medline

13. A. B. Vogel, I. Kanevsky, Y. Che, K. A. Swanson, A. Muik, M. Vormehr, L. M. Kranz, K. C. Walzer, S. Hein, A. Güler, J. Loschko, M. S. Maddur, A. Ota-Setlik, K. Tompkins, J. Cole, B. G. Lui, T. Ziegenhals, A. Plaschke, D. Eisel, S. C. Dany, S. Fesser, S. Erbar, F. Bates, D. Schneider, B. Jesionek, B. Sänger, A. K. Wallisch, Y. Feuchter, H. Junginger, S. A. Krumm, A. P. Heinen, P. Adams-Quack, J. Schlereth, S. Schille, C. Kröner, R. de la Caridad Güimil Garcia, T. Hiller, L. Fischer, R. S. Sellers, S. Choudhary, O. Gonzalez, F. Vascotto, M. R. Gutman, J. A. Fontenot, S. Hall-Ursone, K. Brasky, M. C. Griffor, S. Han, A. A. H. Su, J. A. Lees, N. L. Nedoma, E. H. Mashalidis, P. V. Sahasrabudhe, C. Y. Tan, D. Pavliakova, G. Singh, C. FontesGarfias, M. Pride, I. L. Scully, T. Ciolino, J. Obregon, M. Gazi, R. Carrion, K. J. Alfson, W. V. Kalina, D. Kaushal, P.-Y. Shi, T. Klamp, C. Rosenbaum, A. N. Kuhn, Ö. Türeci, P. R. Dormitzer, K. U. Jansen, U. Sahin, BNT162b vaccines are immunogenic and protect non-human primates against SARS-CoV-2. Cold Spring Harbor Laboratory, 2020.12.11.421008 (2020). 
14. U. Sahin, A. Muik, E. Derhovanessian, I. Vogler, L. M. Kranz, M. Vormehr, A. Baum, K. Pascal, J. Quandt, D. Maurus, S. Brachtendorf, V. Lörks, J. Sikorski, R. Hilker, D. Becker, A.-K. Eller, J. Grützner, C. Boesler, C. Rosenbaum, M.-C. Kühnle, U. Luxemburger, A. Kemmer-Brück, D. Langer, M. Bexon, S. Bolte, K. Karikó, T. Palanche, B. Fischer, A. Schultz, P.-Y. Shi, C. Fontes-Garfias, J. L. Perez, K. A. Swanson, J. Loschko, I. L. Scully, M. Cutler, W. Kalina, C. A. Kyratsous, D. Cooper, P. R. Dormitzer, K. U. Jansen, Ö. Türeci, COVID-19 vaccine BNT162b1 elicits human antibody and $T_{H} 1 \mathrm{~T}$ cell responses. Nature 586, 594-599 (2020). doi:10.1038/s41586-020-2814-7 Medline

15. E. E. Walsh, R. W. Frenck Jr., A. R. Falsey, N. Kitchin, J. Absalon, A. Gurtman, S. Lockhart, K. Neuzil, M. J. Mulligan, R. Bailey, K. A. Swanson, P. Li, K. Koury, W. Kalina, D. Cooper, C. Fontes-Garfias, P.-Y. Shi, Ö. Türeci, K. R. Tompkins, K. E. Lyke, V. Raabe, P. R. Dormitzer, K. U. Jansen, U. Şahin, W. C. Gruber, Safety and Immunogenicity of Two RNA-Based Covid-19 Vaccine Candidates. N. Engl. J. Med. 383, 2439-2450 (2020). doi:10.1056/NEJMoa2027906 Medline

16. L. A. Jackson, E. J. Anderson, N. G. Rouphael, P. C. Roberts, M. Makhene, R. N. Coler, M. P. McCullough, J. D. Chappell, M. R. Denison, L. J. Stevens, A. J. Pruijssers, A. McDermott, B. Flach, N. A. Doria-Rose, K. S. Corbett, K. M. Morabito, S. O'Dell, S. D. Schmidt, P. A. Swanson 2nd, M. Padilla, J. R. Mascola, K. M. Neuzil, H. Bennett, W. Sun, E. Peters, M. Makowski, J. Albert, K. Cross, W. Buchanan, R. Pikaart-Tautges, J. E. Ledgerwood, B. S. Graham, J. H. Beigel; mRNA-1273 Study Group, An mRNA Vaccine against SARS-CoV-2 - Preliminary Report. N. Engl. J. Med. 383, 1920-1931 (2020). doi:10.1056/NEJMoa2022483 Medline

17. E. J. Anderson, N. G. Rouphael, A. T. Widge, L. A. Jackson, P. C. Roberts, M. Makhene, J. D. Chappell, M. R. Denison, L. J. Stevens, A. J. Pruijssers, A. B. McDermott, B. Flach, B. C. Lin, N. A. Doria-Rose, S. O'Dell, S. D. Schmidt, K. S. Corbett, P. A. Swanson 2nd, M. Padilla, K. M. Neuzil, H. Bennett, B. Leav, M. Makowski, J. Albert, K. Cross, V. V. Edara, K. Floyd, M. S. Suthar, D. R. Martinez, R. Baric, W. Buchanan, C. J. Luke, V. K. Phadke, C. A. Rostad, J. E. Ledgerwood, B. S. Graham, J. H. Beigel; mRNA-1273 Study Group, Safety and Immunogenicity of SARS-CoV-2 mRNA-1273 Vaccine in Older Adults. N. Engl. J. Med. 383, 24272438 (2020). doi:10.1056/NEJMoa2028436 Medline

18. L. R. Baden, H. M. El Sahly, B. Essink, K. Kotloff, S. Frey, R. Novak, D. Diemert, S. A. Spector, N. Rouphael, C. B. Creech, J. McGettigan, S. Khetan, N. Segall, J. Solis, A. Brosz, C. Fierro, H. Schwartz, K. Neuzil, L. Corey, P. Gilbert, H. Janes, D. Follmann, M. Marovich, J. Mascola, L. Polakowski, J. Ledgerwood, B. S. Graham, H. Bennett, R. Pajon, C. Knightly, B. Leav, W. Deng, H. Zhou, S. Han, M. Ivarsson, J. Miller, T. Zaks; COVE Study Group, Efficacy and Safety of the mRNA-1273 SARS-CoV-2 Vaccine. N. Engl. J. Med. 384, 403-416 (2021). doi:10.1056/NEJMoa2035389 Medline

19. F. P. Polack, S. J. Thomas, N. Kitchin, J. Absalon, A. Gurtman, S. Lockhart, J. L. Perez, G. Pérez Marc, E. D. Moreira, C. Zerbini, R. Bailey, K. A. Swanson, S. Roychoudhury, K. Koury, P. Li, W. V. Kalina, D. Cooper, R. W. Frenck Jr., L. L. Hammitt, Ö. Türeci, H. Nell, A. Schaefer, S. Ünal, D. B. Tresnan, S. Mather, P. R. Dormitzer, U. Şahin, K. U. Jansen, W. C. Gruber; C4591001 Clinical Trial Group, Safety and Efficacy of the BNT162b2 mRNA Covid-19 Vaccine. N. Engl. J. Med. 383, 2603-2615 (2020). doi:10.1056/NEJMoa2034577 Medline

20. R. R. Goel, S. A. Apostolidis, M. M. Painter, D. Mathew, A. Pattekar, O. Kuthuru, S. Gouma, P. Hicks, W. Meng, A. M. Rosenfeld, S. Dysinger, K. A. Lundgreen, L. KuriCervantes, S. Adamski, A. Hicks, S. Korte, D. A. Oldridge, A. E. Baxter, J. R. Giles, M. E. Weirick, C. M. McAllister, J. Dougherty, S. Long, K. D’Andrea, J. T. Hamilton, M. R. Betts, E. T. Luning Prak, P. Bates, S. E. Hensley, A. R. Greenplate, E. J. Wherry, Distinct antibody and memory B cell responses in SARS-CoV-2 naïve and recovered individuals following mRNA vaccination. Sci. Immunol. 6, eabi6950 (2021). doi:10.1126/sciimmunol.abi6950 Medline

21. J. S. Turner, J. A. O'Halloran, E. Kalaidina, W. Kim, A. J. Schmitz, J. Q. Zhou, T. Lei, M. Thapa, R. E. Chen, J. B. Case, F. Amanat, A. M. Rauseo, A. Haile, X. Xie, M. K. Klebert, T. Suessen, W. D. Middleton, P.-Y. Shi, F. Krammer, S. A. Teefey, M. S. Diamond, R. M. Presti, A. H. Ellebedy, SARS-CoV-2 mRNA vaccines induce persistent human germinal centre responses. Nature 596, 109-113 (2021). doi:10.1038/s41586-021-03738-2 Medline

22. S. L. Linderman, B. S. Chambers, S. J. Zost, K. Parkhouse, Y. Li, C. Herrmann, A. H. Ellebedy, D. M. Carter, S. F. Andrews, N.-Y. Zheng, M. Huang, Y. Huang, D. Strauss, B. H. Shaz, R. L. Hodinka, G. Reyes-Terán, T. M. Ross, P. C. Wilson, R. Ahmed, J. D. Bloom, S. E. Hensley, Potential antigenic explanation for atypical H1N1 infections among middle-aged adults during the 2013-2014 influenza season. Proc. Natl. Acad. Sci. U.S.A. 111, 15798-15803 (2014). doi:10.1073/pnas.1409171111 Medline 23. S. Gouma, K. Kim, M. E. Weirick, M. E. Gumina, A. Branche, D. J. Topham, E. T. Martin, A. S. Monto, S. Cobey, S. E. Hensley, Middle-aged individuals may be in a perpetual state of H3N2 influenza virus susceptibility. Nat. Commun. 11, 4566 (2020). doi:10.1038/s41467-020-18465-x Medline

24. T. T. Wang, J. Sewatanon, M. J. Memoli, J. Wrammert, S. Bournazos, S. K. Bhaumik, B. A. Pinsky, K. Chokephaibulkit, N. Onlamoon, K. Pattanapanyasat, J. K. Taubenberger, R. Ahmed, J. V. Ravetch, IgG antibodies to dengue enhanced for FçRIIIA binding determine disease severity. Science 355, 395-398 (2017). doi:10.1126/science.aai8128 Medline

25. A. E. Ngono, S. Shresta, Immune Response to Dengue and Zika. Annu. Rev. Immunol. 36, 279-308 (2018). doi:10.1146/annurev-immunol-042617-053142 Medline

26. W. Huisman, B. E. E. Martina, G. F. Rimmelzwaan, R. A. Gruters, A. D. M. E. Osterhaus, Vaccine-induced enhancement of viral infections. Vaccine 27, 505512 (2009). doi:10.1016/j.vaccine.2008.10.087 Medline

27. A. Sette, S. Crotty, Adaptive immunity to SARS-CoV-2 and COVID-19. Cell 184 861-880 (2021). doi:10.1016/i.cell.2021.01.007 Medline

28. J. M. Dan, J. Mateus, Y. Kato, K. M. Hastie, E. D. Yu, C. E. Faliti, A. Grifoni, S. I. Ramirez, S. Haupt, A. Frazier, C. Nakao, V. Rayaprolu, S. A. Rawlings, B. Peters, F. Krammer, V. Simon, E. O. Saphire, D. M. Smith, D. Weiskopf, A. Sette, S. Crotty, Immunological memory to SARS-CoV-2 assessed for up to 8 months after infection. Science 371, eabf4063 (2021). doi:10.1126/science.abf4063 Medline

29. C. Rydyznski Moderbacher, S. I. Ramirez, J. M. Dan, A. Grifoni, K. M. Hastie, D. Weiskopf, S. Belanger, R. K. Abbott, C. Kim, J. Choi, Y. Kato, E. G. Crotty, C. Kim, S. A. Rawlings, J. Mateus, L. P. V. Tse, A. Frazier, R. Baric, B. Peters, J. Greenbaum, E. Ollmann Saphire, D. M. Smith, A. Sette, S. Crotty, Antigen-Specific Adaptive Immunity to SARS-CoV-2 in Acute COVID-19 and Associations with Age and Disease Severity. Cell 183, 996-1012.e19 (2020). doi:10.1016/j.cell.2020.09.038 Medline

30. T. A. Reese, K. Bi, A. Kambal, A. Filali-Mouhim, L. K. Beura, M. C. Bürger, B. Pulendran, R.-P. Sekaly, S. C. Jameson, D. Masopust, W. N. Haining, H. W. Virgin, Sequential Infection with Common Pathogens Promotes Human-like Immune Gene Expression and Altered Vaccine Response. Cell Host Microbe 19, 713-719 (2016). doi:10.1016/i.chom.2016.04.003 Medline

31. U. Sahin, A. Muik, I. Vogler, E. Derhovanessian, L. M. Kranz, M. Vormehr, J. Quandt, N. Bidmon, A. Ulges, A. Baum, K. E. Pascal, D. Maurus, S. Brachtendorf, V. Lörks, J. Sikorski, P. Koch, R. Hilker, D. Becker, A.-K. Eller, J. Grützner, M. Tonigold, C. Boesler, C. Rosenbaum, L. Heesen, M.-C. Kühnle, A. Poran, J. Z. Dong, U. Luxemburger, A. Kemmer-Brück, D. Langer, M. Bexon, S. Bolte, T. Palanche, A. Schultz, S. Baumann, A. J. Mahiny, G. Boros, J. Reinholz, G. T. Szabó, K. Karikó, P.Y. Shi, C. Fontes-Garfias, J. L. Perez, M. Cutler, D. Cooper, C. A. Kyratsous, P. R. Dormitzer, K. U. Jansen, Ö. Türeci, BNT162b2 vaccine induces neutralizing antibodies and poly-specific T cells in humans. Nature 595, 572-577 (2021). doi:10.1038/s41586-021-03653-6 Medline

32. J. H. Levine, E. F. Simonds, S. C. Bendall, K. L. Davis, A. D. Amir, M. D. Tadmor, O. Litvin, H. G. Fienberg, A. Jager, E. R. Zunder, R. Finck, A. L. Gedman, I. Radtke, J. R. Downing, D. Pe'er, G. P. Nolan, Data-Driven Phenotypic Dissection of AML Reveals Progenitor-like Cells that Correlate with Prognosis. Cell 162, 184-197 (2015). doi:10.1016/j.cell.2015.05.047 Medline

33. N. Pardi, M. J. Hogan, F. W. Porter, D. Weissman, mRNA vaccines - a new era in vaccinology. Nat. Rev. Drug Discov. 17, 261-279 (2018). doi:10.1038/nrd.2017.243 Medline

34. P.-O. Lang, A. Mendes, J. Socquet, N. Assir, S. Govind, R. Aspinall, Effectiveness of influenza vaccine in aging and older adults: Comprehensive analysis of the evidence. Clin. Interv. Aging 7, 55-64 (2012). doi:10.2147/CIA.S25215 Medline

35. V. Bajaj, N. Gadi, A. P. Spihlman, S. C. Wu, C. H. Choi, V. R. Moulton, Aging, Immunity, and COVID-19: How Age Influences the Host Immune Response to Coronavirus Infections? Front. Physiol. 11, 571416 (2021). doi:10.3389/fphys.2020.571416 Medline

36. B. K. I. Helfand, M. Webb, S. L. Gartaganis, L. Fuller, C.-S. Kwon, S. K. Inouye, The Exclusion of Older Persons From Vaccine and Treatment Trials for Coronavirus Disease 2019-Missing the Target. JAMA Intern. Med. 180, 1546-1549 (2020). doi:10.1001/jamainternmed.2020.5084 Medline 
37. J. Mateus, A. Grifoni, A. Tarke, J. Sidney, S. I. Ramirez, J. M. Dan, Z. C. Burger, S. A. Rawlings, D. M. Smith, E. Phillips, S. Mallal, M. Lammers, P. Rubiro, L. Quiambao, A. Sutherland, E. D. Yu, R. da Silva Antunes, J. Greenbaum, A. Frazier, A. J. Markmann, L. Premkumar, A. de Silva, B. Peters, S. Crotty, A. Sette, D. Weiskopf, Selective and cross-reactive SARS-CoV-2 T cell epitopes in unexposed humans. Science 370, 89-94 (2020). doi:10.1126/science.abd3871 Medline

38. R. S. Herati, A. Muselman, L. Vella, B. Bengsch, K. Parkhouse, D. Del Alcazar, J. Kotzin, S. A. Doyle, P. Tebas, S. E. Hensley, L. F. Su, K. E. Schmader, E. J. Wherry, Successive annual influenza vaccination induces a recurrent oligoclonotypic memory response in circulating T follicular helper cells. Sci. Immunol. 2, eaag2152 (2017). doi:10.1126/sciimmunol.aag2152 Medline

39. J. M. Dan, C. S. Lindestam Arlehamn, D. Weiskopf, R. da Silva Antunes, C. HavenarDaughton, S. M. Reiss, M. Brigger, M. Bothwell, A. Sette, S. Crotty, A CytokineIndependent Approach To Identify Antigen-Specific Human Germinal Center T Follicular Helper Cells and Rare Antigen-Specific CD4+ T Cells in Blood. J. Immunol. 197, 983-993 (2016). doi:10.4049/iimmunol.1600318 Medline

40. A. Grifoni, D. Weiskopf, S. I. Ramirez, J. Mateus, J. M. Dan, C. R. Moderbacher, S. A. Rawlings, A. Sutherland, L. Premkumar, R. S. Jadi, D. Marrama, A. M. de Silva, A. Frazier, A. F. Carlin, J. A. Greenbaum, B. Peters, F. Krammer, D. M. Smith, S. Crotty, A. Sette, Targets of T Cell Responses to SARS-CoV-2 Coronavirus in Humans with COVID-19 Disease and Unexposed Individuals. Cell 181, 14891501.e15 (2020). doi:10.1016/i.cell.2020.05.015 Medline

41. S. Crotty, $T$ follicular helper cell differentiation, function, and roles in disease. Immunity 41, 529-542 (2014). doi:10.1016/i.immuni.2014.10.004 Medline

42. S. Crotty, T Follicular Helper Cell Biology: A Decade of Discovery and Diseases. Immunity 50, 1132-1148 (2019). doi:10.1016/i.immuni.2019.04.011 Medline

43. L. A. Vella, M. Buggert, S. Manne, R. S. Herati, I. Sayin, L. Kuri-Cervantes, I. Bukh Brody, K. C. O'Boyle, H. Kaprielian, J. R. Giles, S. Nguyen, A. Muselman, J. P. Antel, A. Bar-Or, M. E. Johnson, D. H. Canaday, A. Naji, V. V. Ganusov, T. M. Laufer, A. D. Wells, Y. Dori, M. G. Itkin, M. R. Betts, E. J. Wherry, T follicular helper cells in human efferent lymph retain lymphoid characteristics. J. Clin. Invest. 129, 3185-3200 (2019). doi:10.1172/JCl125628 Medline

44. M. Locci, C. Havenar-Daughton, E. Landais, J. Wu, M. A. Kroenke, C. L. Arlehamn, L. F. Su, R. Cubas, M. M. Davis, A. Sette, E. K. Haddad, P. Poignard, S. Crotty; International AIDS Vaccine Initiative Protocol C Principal Investigators, Human circulating PD-1+CXCR3-CXCR5+ memory Tfh cells are highly functional and correlate with broadly neutralizing HIV antibody responses. Immunity $39,758-$ 769 (2013). doi:10.1016/i.immuni.2013.08.031 Medline

45. R. S. Herati, M. A. Reuter, D. V. Dolfi, K. D. Mansfield, H. Aung, O. Z. Badwan, R. K. Kurupati, S. Kannan, H. Ertl, K. E. Schmader, M. R. Betts, D. H. Canaday, E. J. Wherry, Circulating CXCR5+PD-1+ response predicts influenza vaccine antibody responses in young adults but not elderly adults. J. Immunol. 193, 3528-3537 (2014). doi:10.4049/jimmunol.1302503 Medline

46. S.-E. Bentebibel, S. Lopez, G. Obermoser, N. Schmitt, C. Mueller, C. Harrod, E. Flano, A. Mejias, R. A. Albrecht, D. Blankenship, H. Xu, V. Pascual, J. Banchereau, A. Garcia-Sastre, A. K. Palucka, 0. Ramilo, H. Ueno, Induction of ICOS+CXCR3+CXCR5+ TH cells correlates with antibody responses to influenza vaccination. Sci. Transl. Med. 5, 176ra32 (2013). doi:10.1126/scitransImed.3005191 Medline

47. S.-E. Bentebibel, S. Khurana, N. Schmitt, P. Kurup, C. Mueller, G. Obermoser, A. K. Palucka, R. A. Albrecht, A. Garcia-Sastre, H. Golding, H. Ueno, ICOS(+)PD$1(+)$ CXCR3(+) T follicular helper cells contribute to the generation of high-avidity antibodies following influenza vaccination. Sci. Rep. 6, 26494-26494 (2016). doi:10.1038/srep26494 Medline

48. G. Lindgren, S. Ols, F. Liang, E. A. Thompson, A. Lin, F. Hellgren, K. Bahl, S. John, O. Yuzhakov, K. J. Hassett, L. A. Brito, H. Salter, G. Ciaramella, K. Loré, Induction of Robust $B$ cell responses after influenza mRNA vaccination is accompanied by circulating hemagglutinin-specific ICOS+ PD-1+ CXCR3+ T follicular helper cells. Front. Immunol. 8, 1539-1539 (2017). doi:10.3389/fimmu.2017.01539 Medline

49. D. Lau, L. Y. L. Lan, S. F. Andrews, C. Henry, K. T. Rojas, K. E. Neu, M. Huang, Y. Huang, B. DeKosky, A. E. Palm, G. C. Ippolito, G. Georgiou, P. C. Wilson, Low CD21 expression defines a population of recent germinal center graduates primed for plasma cell differentiation. Sci. Immunol. 2, 1-14 (2017). doi:10.1126/sciimmunol.aai8153 Medline

50. A. H. Ellebedy, K. J. L. Jackson, H. T. Kissick, H. I. Nakaya, C. W. Davis, K. M. Roskin,
A. K. McElroy, C. M. Oshansky, R. Elbein, S. Thomas, G. M. Lyon, C. F. Spiropoulou, A. K. Mehta, P. G. Thomas, S. D. Boyd, R. Ahmed, Defining antigen-specific plasmablast and memory B cell subsets in human blood after viral infection or vaccination. Nat. Immunol. 17, 1226-1234 (2016). doi:10.1038/ni.3533 Medline

51. C. Havenar-Daughton, M. Lindqvist, A. Heit, J. E. Wu, S. M. Reiss, K. Kendric, S. Bélanger, S. P. Kasturi, E. Landais, R. S. Akondy, H. M. McGuire, M. Bothwell, P. A. Vagefi, E. Scully, G. D. Tomaras, M. M. Davis, P. Poignard, R. Ahmed, B. D. Walker, B. Pulendran, M. J. McElrath, D. E. Kaufmann, S. Crotty; IAVI Protocol C Principal Investigators, CXCL13 is a plasma biomarker of germinal center activity. Proc. Natl. Acad. Sci. U.S.A. 113, 2702-2707 (2016). doi:10.1073/pnas.1520112113 Medline

52. J. S. Turner, W. Kim, E. Kalaidina, C. W. Goss, A. M. Rauseo, A. J. Schmitz, L. Hansen, A. Haile, M. K. Klebert, I. Pusic, J. A. O'Halloran, R. M. Presti, A. H. Ellebedy, SARS-CoV-2 infection induces long-lived bone marrow plasma cells in humans. Nature 595, 421-425 (2021). doi:10.1038/s41586-021-03647-4 Medline

53. F. F. K. Mensah, C. W. Armstrong, V. Reddy, A. S. Bansal, S. Berkovitz, M. J. Leandro, G. Cambridge, CD24 Expression and B Cell Maturation Shows a Novel Link With Energy Metabolism: Potential Implications for Patients With Myalgic Encephalomyelitis/Chronic Fatigue Syndrome. Front. Immunol. 9, 2421 (2018). doi:10.3389/fimmu.2018.02421 Medline

54. S. Wang, J. Wang, V. Kumar, J. L. Karnell, B. Naiman, P. S. Gross, S. Rahman, K. Zerrouki, R. Hanna, C. Morehouse, N. Holoweckyj, H. Liu, Z. Manna, R. GoldbachMansky, S. Hasni, R. Siegel, M. Sanjuan, K. Streicher, M. P. Cancro, R. Kolbeck, R. Ettinger; Autoimmunity Molecular Medicine Team, IL-21 drives expansion and plasma cell differentiation of autoreactive CD11 ${ }^{\text {hiT }}$-bet ${ }^{+}$B cells in SLE. Nat Commun. 9, 1758 (2018). doi:10.1038/s41467-018-03750-7 Medline

55. M. P. Cancro, Age-Associated B Cells. Annu. Rev. Immunol. 38, 315-340 (2020). doi:10.1146/annurev-immunol-092419-031130 Medline

56. S. A. Jenks, K. S. Cashman, E. Zumaquero, U. M. Marigorta, A. V. Patel, X. Wang, D. Tomar, M. C. Woodruff, Z. Simon, R. Bugrovsky, E. L. Blalock, C. D. Scharer, C. M. Tipton, C. Wei, S. S. Lim, M. Petri, T. B. Niewold, J. H. Anolik, G. Gibson, F. E.-H. Lee, J. M. Boss, F. E. Lund, I. Sanz, Distinct Effector B Cells Induced by Unregulated Toll-like Receptor 7 Contribute to Pathogenic Responses in Systemic Lupus Erythematosus. Immunity 49, 725-739.e6 (2018). doi:10.1016/i.immuni.2018.08.015 Medline

57. Y. Huang, C. Yang, X.-F. Xu, W. Xu, S.-W. Liu, Structural and functional properties of SARS-CoV-2 spike protein: Potential antivirus drug development for COVID-19. Acta Pharmacol. Sin. 41, 1141-1149 (2020). doi:10.1038/s41401-020-0485-4 Medline

58. G. R. Pullen, M. G. Fitzgerald, C. S. Hosking, Antibody avidity determination by ELISA using thiocyanate elution. J. Immunol. Methods 86, 83-87 (1986) doi:10.1016/0022-1759(86)90268-1 Medline

59. S. Khurana, N. Verma, J. W. Yewdell, A. K. Hilbert, F. Castellino, M. Lattanzi, G. Del Giudice, R. Rappuoli, H. Golding, MF59 adjuvant enhances diversity and affinity of antibody-mediated immune response to pandemic influenza vaccines. Sci. Transl. Med. 3, 85ra48 (2011). doi:10.1126/scitranslmed.3002336 Medline

60. M. Narita, Y. Matsuzono, Y. Takekoshi, S. Yamada, O. Itakura, M. Kubota, H. Kikuta, T. Togashi, Analysis of mumps vaccine failure by means of avidity testing for mumps virus-specific immunoglobulin G. Clin. Diagn. Lab. Immunol. 5, 799-803 (1998). doi:10.1128/CDLI.5.6.799-803.1998 Medline

61. R. H. Haberman, R. Herati, D. Simon, M. Samanovic, R. B. Blank, M. Tuen, S. B. Koralov, R. Atreya, K. Tascilar, J. R. Allen, R. Castillo, A. R. Cornelius, P. Rackoff, G. Solomon, S. Adhikari, N. Azar, P. Rosenthal, P. Izmirly, J. Samuels, B. Golden, S. M. Reddy, M. F. Neurath, S. B. Abramson, G. Schett, M. J. Mulligan, J. U. Scher, Methotrexate hampers immunogenicity to BNT162b2 mRNA COVID-19 vaccine in immune-mediated inflammatory disease. Ann. Rheum. Dis. 80, 1339-1344 (2021). doi:10.1136/annrheumdis-2021-220597 Medline

62. K. Bahl, J. J. Senn, O. Yuzhakov, A. Bulychev, L. A. Brito, K. J. Hassett, M. E. Laska, M. Smith, Ö. Almarsson, J. Thompson, A. M. Ribeiro, M. Watson, T. Zaks, G. Ciaramella, Preclinical and Clinical Demonstration of Immunogenicity by mRNA Vaccines against H10N8 and H7N9 Influenza Viruses. Mol. Ther. 25, 1316-1327 (2017). doi:10.1016/i.ymthe.2017.03.035 Medline

63. R. S. Herati, L. V. Silva, L. A. Vella, A. Muselman, C. Alanio, B. Bengsch, R. K. Kurupati, S. Kannan, S. Manne, A. V. Kossenkov, D. H. Canaday, S. A. Doyle, H. C J. Ertl, K. E. Schmader, E. J. Wherry, Vaccine-induced ICOS ${ }^{+}$D $38^{+}$circulating Tfh 
are sensitive biosensors of age-related changes in inflammatory pathways. Cell Reports Medicine 2, 100262 (2021). doi:10.1016/i.xcrm.2021.100262 Medline

64. J. T. Sandberg, S. Ols, M. Löfling, R. Varnaitè, G. Lindgren, O. Nilsson, L. Rombo, M. Kalén, K. Loré, K. Blom, H.-G. Ljunggren, Activation and Kinetics of Circulating T Follicular Helper Cells, Specific Plasmablast Response, and Development of Neutralizing Antibodies following Yellow Fever Virus Vaccination. J. Immunol. 207, 1033-1043 (2021). doi:10.4049/iimmunol.2001381 Medline

65. A. Ellebedy, J. Turner, J. O'Halloran, E. Kalaidina, W. Kim, A. Schmitz, T. Lei, M. Thapa, R. Chen, J. Case, F. Amanat, A. Rauseo, A. Haile, M. Klebert, T. Suessen, W. Middleton, F. Krammer, S. Teefey, M. Diamond, R. Presti, X. Xie, P.-Y. Shi, SARSCoV-2 mRNA vaccines induce a robust germinal centre reaction in humans Nature Portfolio (2021), doi:10.21203/rs.3.rs-310773/v1.

66. J. S. Turner, J. Q. Zhou, J. Han, A. J. Schmitz, A. A. Rizk, W. B. Alsoussi, T. Lei, M. Amor, K. M. Mclntire, P. Meade, S. Strohmeier, R. I. Brent, S. T. Richey, A. Haile, Y. R. Yang, M. K. Klebert, T. Suessen, S. Teefey, R. M. Presti, F. Krammer, S. H. Kleinstein, A. B. Ward, A. H. Ellebedy, Human germinal centres engage memory and naive B cells after influenza vaccination. Nature 586, 127-132 (2020). doi:10.1038/s41586-020-2711-0 Medline

67. K. Lederer, D. Castaño, D. Gómez Atria, T. H. Oguin 3rd, S. Wang, T. B. Manzoni, H. Muramatsu, M. J. Hogan, F. Amanat, P. Cherubin, K. A. Lundgreen, Y. K. Tam, S. H. Y. Fan, L. C. Eisenlohr, I. Maillard, D. Weissman, P. Bates, F. Krammer, G. D. Sempowski, N. Pardi, M. Locci, SARS-CoV-2 mRNA Vaccines Foster Potent Antigen-Specific Germinal Center Responses Associated with Neutralizing Antibody Generation. Immunity 53, 1281-1295.e5 (2020). doi:10.1016/i.immuni.2020.11.009 Medline

68. J. L. Schultze, A. C. Aschenbrenner, COVID-19 and the human innate immune system. Cell 184, 1671-1692 (2021). doi:10.1016/j.cell.2021.02.029 Medline

69. L. L. Seifert, C. Si, D. Saha, M. Sadic, M. de Vries, S. Ballentine, A. Briley, G. Wang, A. M. Valero-Jimenez, A. Mohamed, U. Schaefer, H. M. Moulton, A. García-Sastre, S. Tripathi, B. R. Rosenberg, M. Dittmann, The ETS transcription factor ELF1 regulates a broadly antiviral program distinct from the type I interferon response. PLOS Pathog. 15, e1007634 (2019). doi:10.1371/journal.ppat.1007634 Medline

70. M. D. Robinson, D. J. McCarthy, G. K. Smyth, edgeR: A Bioconductor package for differential expression analysis of digital gene expression data. Bioinformatics 26 , 139-140 (2010). doi:10.1093/bioinformatics/btp616 Medline

71. J. C. Marshall, S. Murthy, J. Diaz, N. K. Adhikari, D. C. Angus, Y. M. Arabi, K. Baillie, M. Bauer, S. Berry, B. Blackwood, M. Bonten, F. Bozza, F. Brunkhorst, A. Cheng, M. Clarke, V. Q. Dat, M. de Jong, J. Denholm, L. Derde, J. Dunning, X. Feng, T. Fletcher, N. Foster, R. Fowler, N. Gobat, C. Gomersall, A. Gordon, T. Glueck, M. Harhay, C. Hodgson, P. Horby, Y. J. Kim, R. Kojan, B. Kumar, J. Laffey, D. Malvey, I. Martin-Loeches, C. McArthur, D. McAuley, S. McBride, S. McGuinness, L. Merson, S. Morpeth, D. Needham, M. Netea, M.-D. Oh, S. Phyu, S. Piva, R. Qiu, H. Salisu-Kabara, L. Shi, N. Shimizu, J. Sinclair, S. Tong, A. Turgeon, T. Uyeki, F. van de Veerdonk, S. Webb, P. Williamson, T. Wolf, J. Zhang; WHO Working Group on the Clinical Characterisation and Management of COVID-19 infection, A minimal common outcome measure set for COVID-19 clinical research. Lancet Infect. Dis. 20, e192-e197 (2020). doi:10.1016/S1473-3099(20)30483-7 Medline

Acknowledgments: We would like to thank the participants who joined our studies. We would like to thank all of the NYU Vaccine Center staff, including Juanita Erb, Gali Moritz, Mahnoor Ali, Stephanie Rettig, Heekoung Youn, Brooklyn Henderson, Lisa Zhao, and Harry Lambert for their help in these studies. We thank Maren De Vries for the viral stock production and titration. We thank Meike Dittmann and The Microscopy Laboratory at NYU Langone Health for the use of their microscopes. We thank the Office of Science \& Research High-Containment Laboratories at NYU Grossman School of Medicine for their support in the completion of this research and Ludovic Desvignes for his management of the NYU Langone Biosafety Level 3 laboratory. We also thank the research clinicians at the NYU Langone Vaccine Center Manhattan clinic for assistance with study participant visits including: Tamia Davis, Vanessa Raabe, Purvi Parikh, Alexander McMeeking, Rebecca Pellet Madan, and Bo Shopsin. Funding: This study was supported by National Institutes of Health grants Al114852, AI082630, and Al158617 (to R.S.H.), by National Institutes of Health grant Al148574 (to M.J.M.), and by NIH (R21AI110830, R21Al137752, and R01HL125816), LEO Foundation Grant (LF-OC-20-000351), the Judith and Stewart Colton Center for Autoimmunity Pilot grant (to S.B.K.). The Microscopy Laboratory at NYU
Langone Health is supported in part by NYU Langone Health's Laura and Isaac Perlmutter Cancer Center Support (grant P30CA016087) from the National Cancer Institute. Author contributions: M.I.S., A.C., R.S.H., and M.J.M. conceptualized and designed the study. M.I.S., A.C., S.L.G-G., and R.S.H. developed methodologies, analyzed and interpreted data, and drafted the article. M.I.S, A.C., J.R.A, S.L.G-G., T.K., J.P.W., S.W.H., M.T., and R.S.H. performed experiments. Original sample collection and processing were performed by M.I.S, A.C., T.K., J.P.W., S.W.H, R.S.H. M.I.S., A.C., S.L.G-G., and R.S.H. performed data curation. R.S.H. performed statistical analyses. The manuscript was reviewed and edited by M.I.S., A.C., S.L.G-G., S.B.K., J.P.W., T.K., M.T., M.J.M., S.H., and R.S.H. Competing interests: MJM reported potential competing interests: laboratory research and clinical trials contracts for studies involving SARS-CoV-2 vaccines and monoclonal antibodies directed against SARS-CoV-2 with Lilly, Pfizer (exclusive of the current work), and Sanofi; contract funding from USG/HHS/BARDA for research specimen characterization and repository; research grant funding from USG/HHS/NIH for SARS-CoV-2 vaccine and monoclonal antibody clinical trials; personal fees for Scientific Advisory Board service from Merck, Meissa Vaccines, Inc. and Pfizer. RSH has received research support from CareDx for SARS-CoV-2 vaccine studies. Data availability: All data associated with this study are in the paper or supplementary materials. This work is licensed under a Creative Commons Attribution 4.0 International (CC BY 4.0) license, which permits unrestricted use, distribution, and reproduction in any medium, provided the original work is properly cited. To view a copy of this license, visit https://creativecommons.org/licenses/by/4.0/. This license does not apply to figures/photos/artwork or other content included in the article that is credited to a third party; obtain authorization from the rights holder before using this material.

Submitted 7 April 2021

Accepted 1 December 2021

Published First Release 7 December 2021

10.1126/scitransImed.abi8961 
A

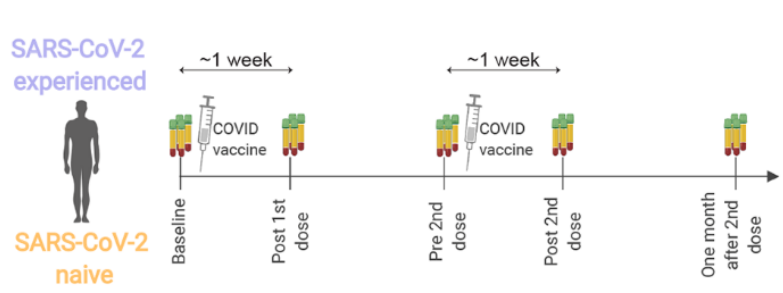

D

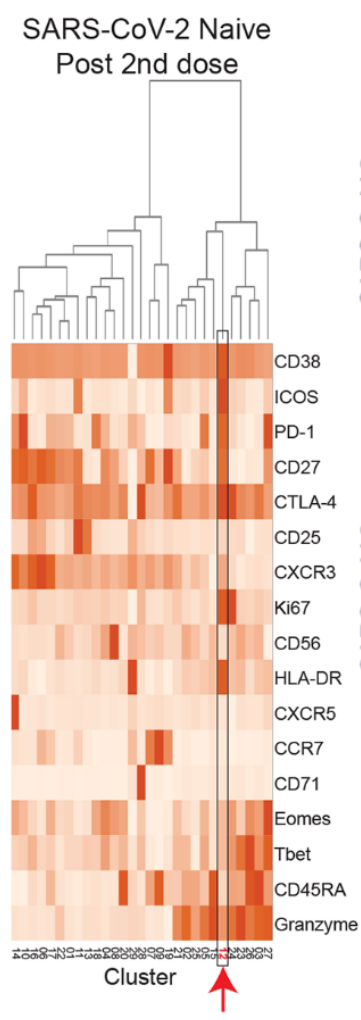

G $\quad \mathrm{CD} 4^{+} \mathrm{T}$ cell activation

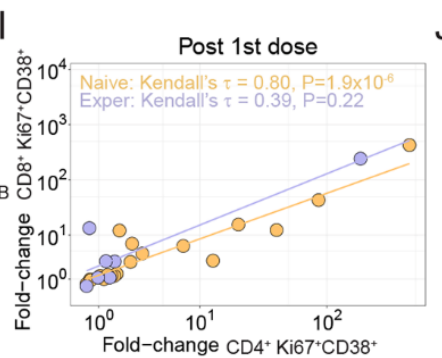

B

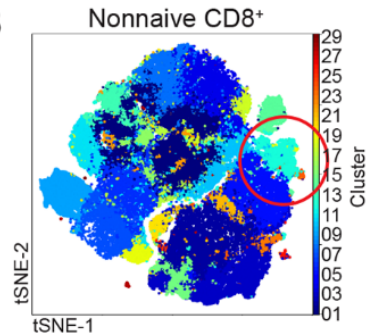

C Nonnaive $\mathrm{CD} 8^{+}-$Post 2nd dose

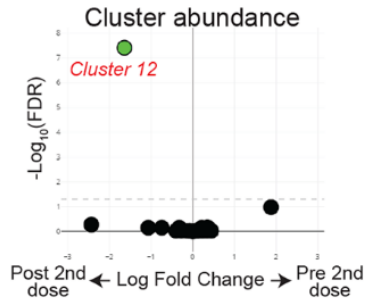

E

F $\quad$ Activated $\mathrm{CD} 8^{+}$
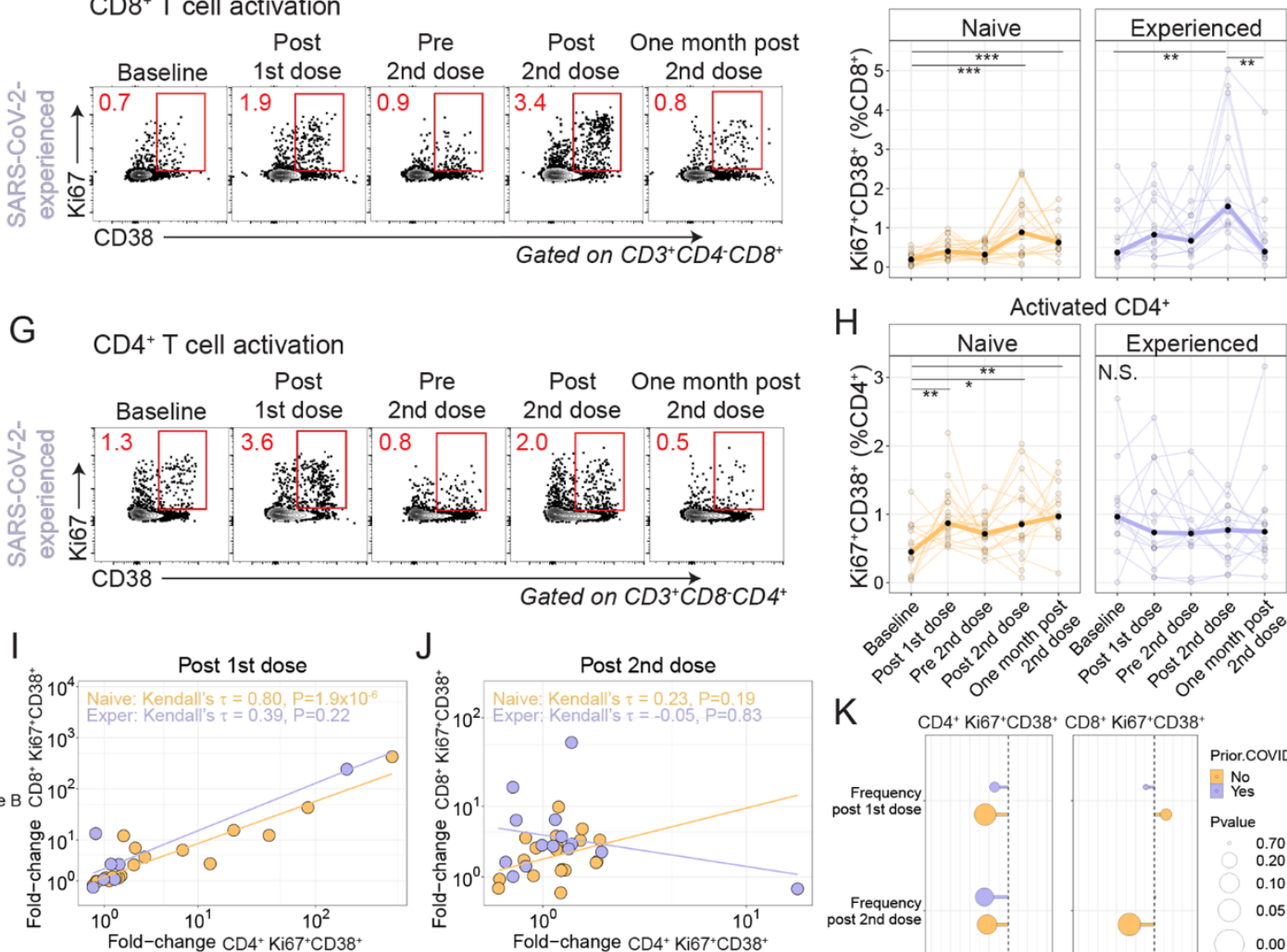

$\mathrm{H}$

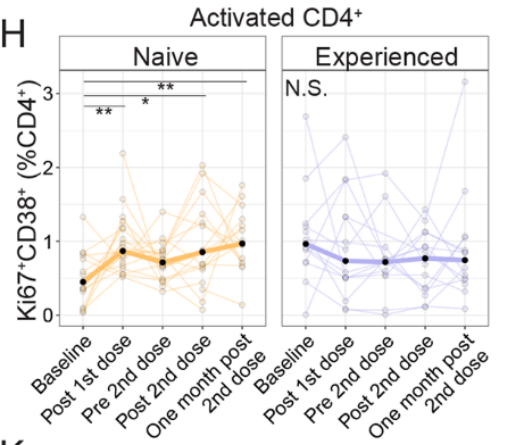

$\mathrm{K}$

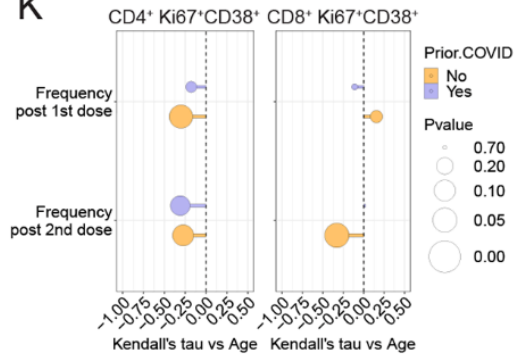

Fig. 1. mRNA vaccination induces $\mathrm{CD}^{+}$and $C D 8^{+} \mathrm{T}$ cell responses. (A) Study schematic. (B) Non-naive $\mathrm{CD} 8^{+} \mathrm{T}$ cells from all participants were colored using Phenograph clusters and projected using tSNE. The circled region indicates cluster 12. (C) Phenograph cluster abundance for non-naive CD8+ T cells was compared using edgeR for all participants before and after the second vaccination. (D) The heatmap shows non-naive CD8 ${ }^{+} \mathrm{T}$ cell cluster protein expression for SARS-CoV-2-naive participants after the second vaccination. The red arrow indicates cluster 12. (E) Example flow cytometry plots show CD8 $8^{+} \mathrm{T}$ cell expression of $\mathrm{Ki} 67$ and $\mathrm{CD} 38$ in an experienced participant. Red numbers indicate frequency. (F) Summary data for $\mathrm{Ki} 67^{+} \mathrm{CD} 38^{+}$expression in $\mathrm{CD} 8^{+} \mathrm{T}$ cells is shown by cohort. ${ }^{*} P<0.01$ and ${ }^{* * *} P<0.001$ by Dunn's post-test for SARS-CoV-2-naive (orange, $\mathrm{n}=19$ ) and SARS-CoV-2experienced (purple, $n=14$ ) participants. Thick lines represent median of values. (G) Example flow cytometry plots show CD4 ${ }^{+} \mathrm{T}$ cell expression of Ki67 and CD38 in a SARS-CoV-2 experienced participant. Red numbers indicate frequency. $(\mathrm{H})$ Summary data for $\mathrm{Ki67}{ }^{+} \mathrm{CD} 38^{+}$expression in $\mathrm{CD} 4{ }^{+} \mathrm{T}$ cells is shown by cohort. ${ }^{*} P<0.05$, ${ }^{* *} P<0.01$, and ${ }^{* *} P<0.001$ by Dunn's post-test for SARS-CoV-2-naive (orange, $\mathrm{n}=19$ ) and SARS-CoV-2-experienced (purple, $\mathrm{n}=14$ ) participants. Thick lines represent median of values. (I and J) Kendall rank correlations are shown for the foldchanges were calculated for $\mathrm{CD} 8^{+} \mathrm{Ki} 67^{+} \mathrm{CD} 38^{+}$and $\mathrm{CD} 4^{+} \mathrm{Ki} 67^{+} \mathrm{CD} 38^{+} \mathrm{T}$ cells at one week after first dose compared to baseline (I) or at one week after second dose compared to Pre 2nd dose time point $(\mathrm{J})$ for SARS-CoV-2-naive (orange, $\mathrm{n}=19$ ) and SARS-CoV-2-experienced (purple, $\mathrm{n}=12$ ) participants. (K) A Kendall correlation is shown for the comparison of $\mathrm{CD} 4^{+} \mathrm{Ki} 67^{+} \mathrm{CD} 38^{+}$subset versus age. Nominal $P$-values are shown for SARS-CoV-2-naive (orange, $\mathrm{n}=21$ ) and SARS-CoV-2-experienced (purple, $\mathrm{n}=14$ ) participants. 
A

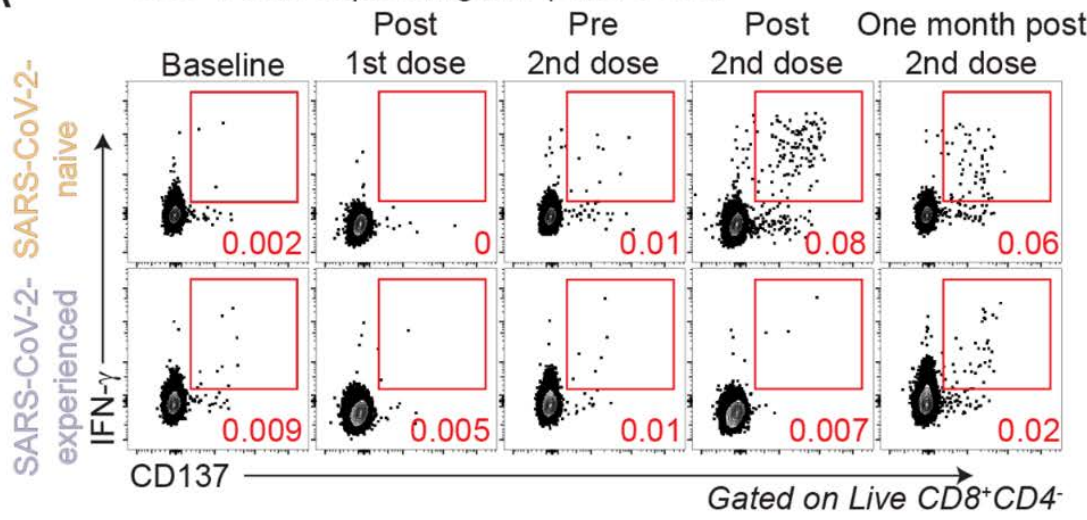

C

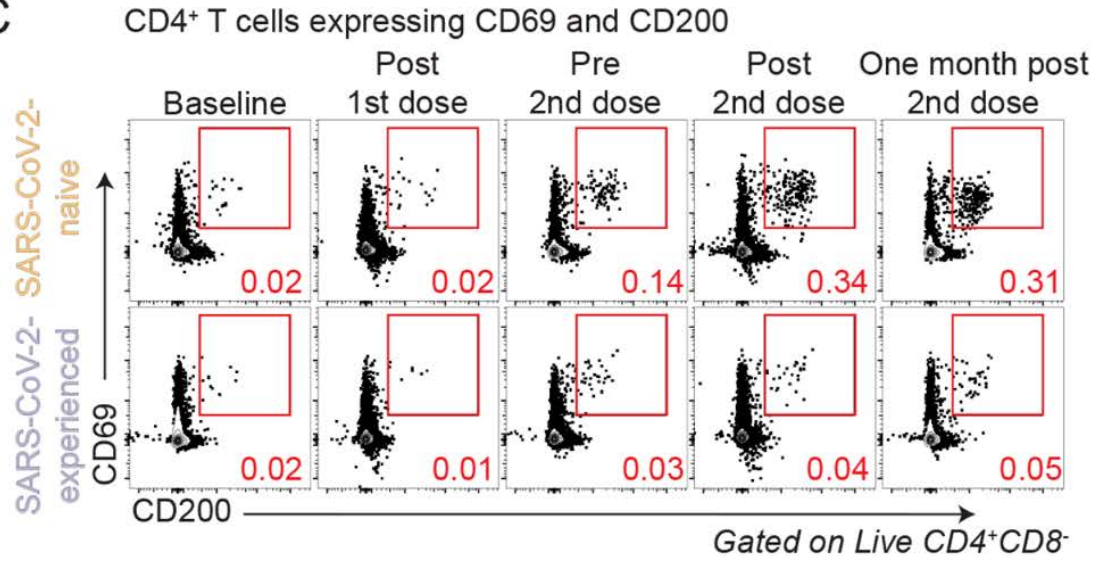

B

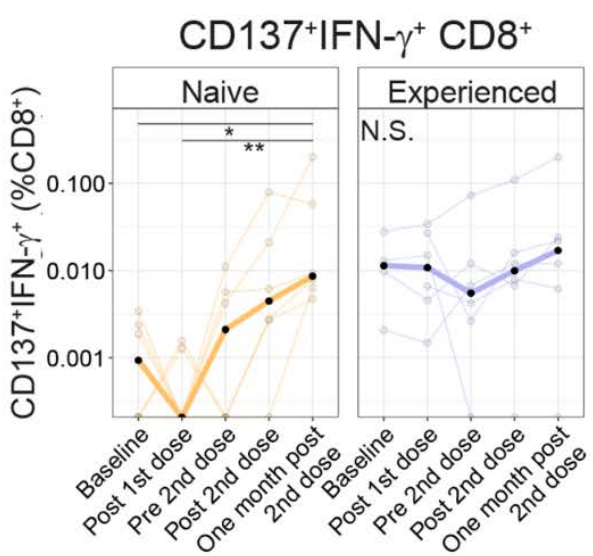

$\mathrm{D}$

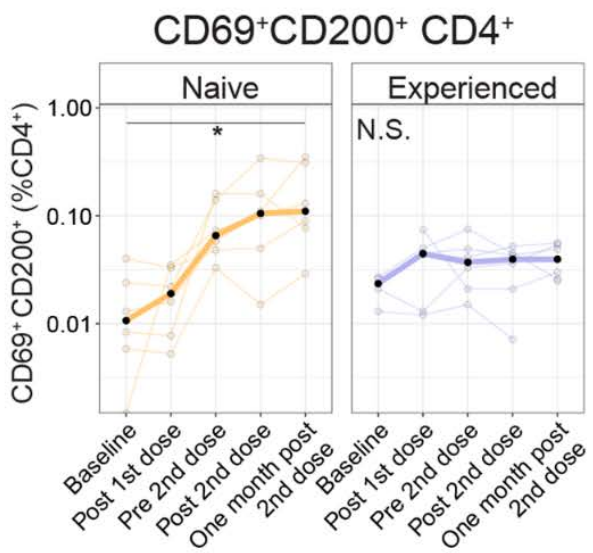

Fig. 2. Antigen-specific T cells are induced by vaccination. PBMCs were rested overnight then stimulated for 20 hours with SARS-CoV-2 spike peptides in the presence of monensin, followed by phenotypic analysis. (A) Example flow cytometry plots are shown for $\mathrm{CD}^{+} \mathrm{T}$ cells isolated from SARS-CoV-2-naive and SARS-CoV-2experienced individuals evaluated for the expression of IFN- $y$ and CD137 for the full time course. (B) Summary data of IFN- $y$ and CD137 expression are shown for SARS-CoV-2-naive (orange, $n=6$ ) and SARS-CoV-2experienced (purple, $n=6$ ) participants. Thick lines represent median of values. (C) Example flow cytometry plots are shown for $\mathrm{CD}^{+} \mathrm{T}$ cells isolated from SARS-CoV-2-naive and SARS-CoV-2-experienced individuals evaluated for the expression of CD69 and CD200 for the full time course. (D) Summary data are shown for SARS-CoV-2-naive (orange, $n=6$ ) and SARS-CoV-2-experienced (purple, $n=6$ ) participants. Thick lines represent mean values. Red numbers in $(A)$ and $(C)$ indicate frequency. ${ }^{*} P<0.05$ and ${ }^{* *} P<0.01$ by KruskalWallis analvsis and Dunn's post-test. 
A
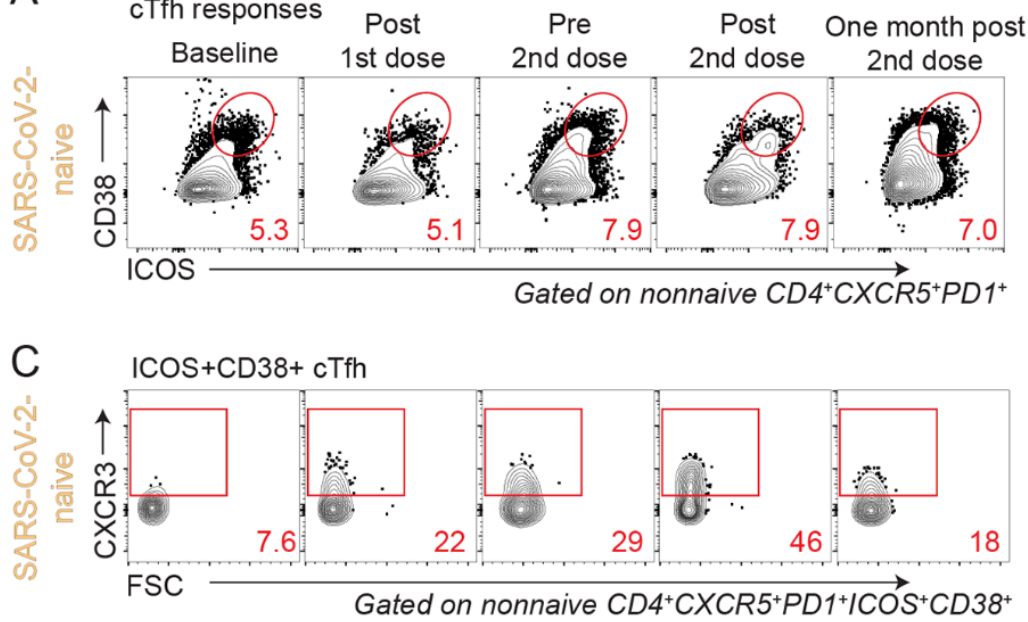

E
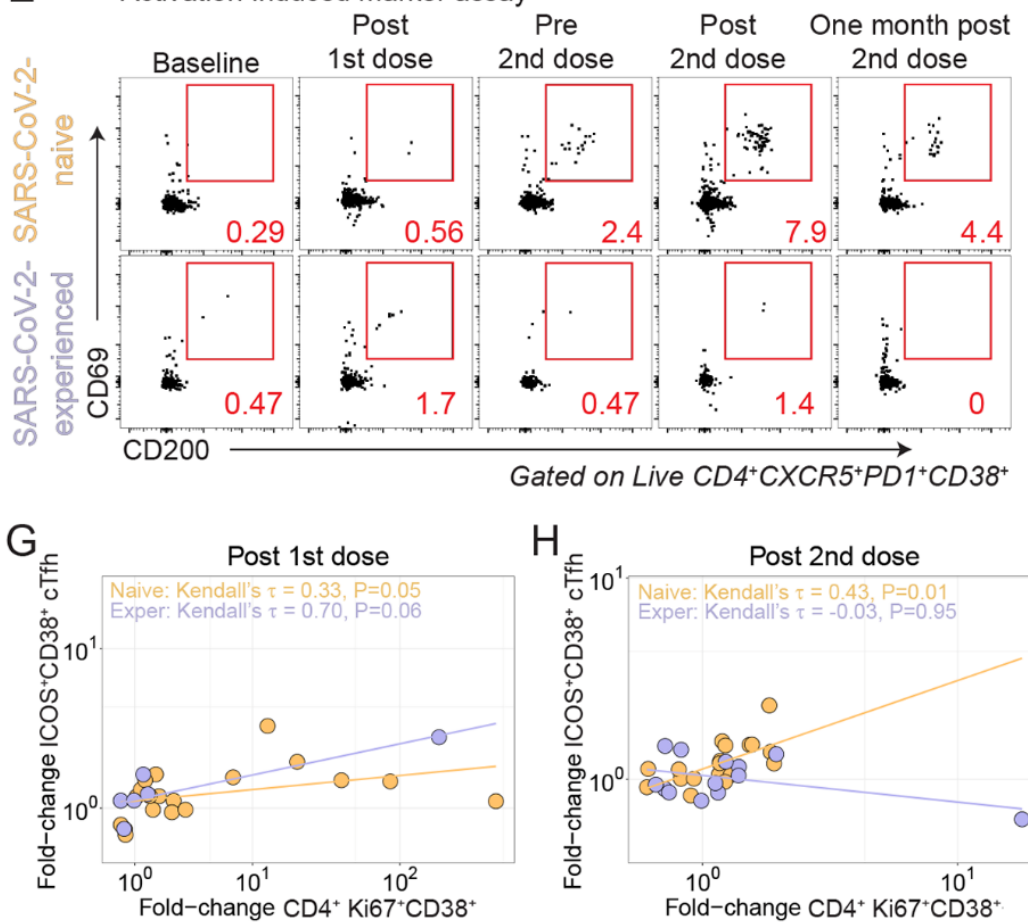

B

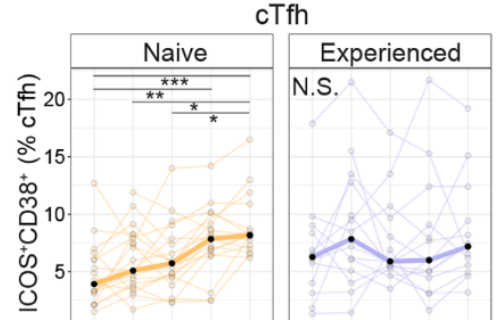

D

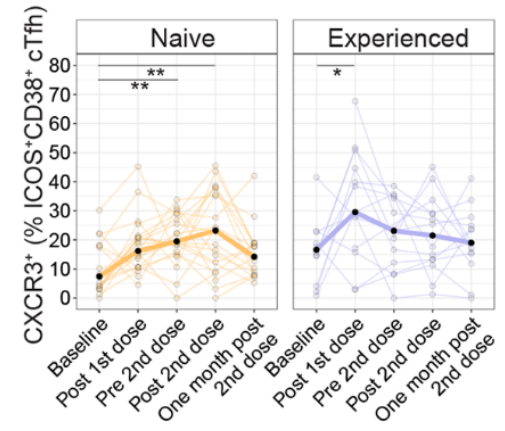

$\mathrm{F}$
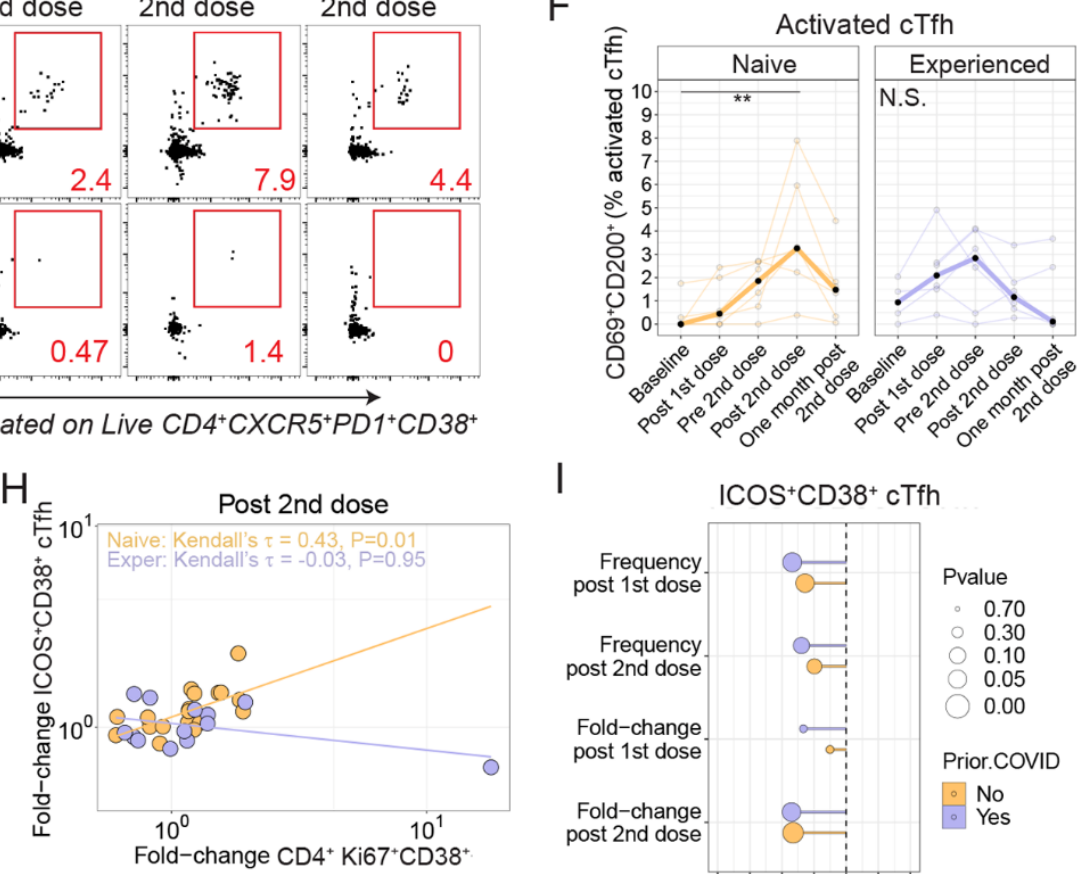

I

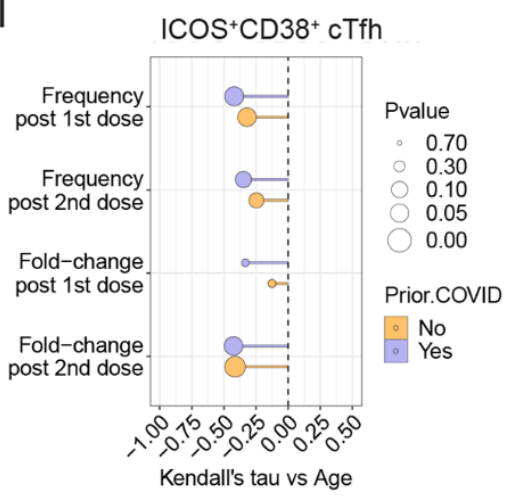


Fig. 3. Circulating $T$ follicular helper cells are differentially induced in SARS-CoV-2 naive and experienced individuals after vaccination. (A) Example flow cytometry plots are shown for a sample from a naive participant stained for ICOS and CD38 in cTfh. Red numbers indicate frequency. (B) Summary data are shown for expression of ICOS and CD38 in cTfh for SARS-CoV-2-naive (orange, $n=21$ ) and SARS-CoV-2-experienced (purple, $\mathrm{n}=14$ ) participants. Thick lines represent median of values. (C) Example flow cytometry plots are shown for CXCR3 expression in $\mathrm{ICOS}^{+} \mathrm{CD}_{3} 8^{+} \mathrm{CTfh}$. Red numbers indicate frequency. FSC, forward scatter. (D) Summary data for CXCR3 expression is shown for ICOS ${ }^{+} \mathrm{CD} 38^{+} \mathrm{CTfh}$ isolated from SARS-CoV-2-naive (orange, $\mathrm{n}=21$ ) and SARS-CoV-2-experienced (purple, $n=14$ ) participants. Thick lines represent median of values. $(E)$ PBMCs were stimulated with overlapping SARS-CoV-2 spike peptides for 20 hours followed by phenotypic analysis. CD38 hi cTfh were assessed for expression of CD69 and CD200. Red numbers indicate frequency. (F) Summary plots for CD69 and CD200 coexpression among CD38 hi cTfh are shown for SARS-CoV-2-naive (orange, $n=6$ ) and SARS-CoV-2-experienced (purple, $n=6$ ) participants. Thick lines represent median of values. $\left(\mathrm{G}\right.$ and $\mathrm{H}$ ) Kendall correlations are shown between the fold-change in $\mathrm{ICOS}{ }^{+} \mathrm{CD} 38^{+} \mathrm{cTfh}$ and $\mathrm{Ki} 67^{+} \mathrm{CD} 38^{+} \mathrm{CD}^{+}$ T cells at one week Post 1st dose compared to baseline $(G)$ or one week after second dose compared to Pre 2nd dose $(\mathrm{H})$ for SARS-CoV-2-naive (orange, $\mathrm{n}=19$ ) and SARS-CoV-2-experienced (purple, $\mathrm{n}=12$ ) participants. (I) Kendall correlations are shown for the comparison of $\mathrm{CD} 4^{+} \mathrm{Ki} 67^{+} \mathrm{CD} 38^{+}$subset versus age. Fold-change Post 1 st dose is relative to baseline, and fold-change Post 2 nd dose is relative to Pre 2 nd dose time point. Nominal $P$-values shown. For all plots, ${ }^{*} P<0.05$, ${ }^{*} P<0.01$, and ${ }^{* * *} P<0.001$ by Dunn's post-test unless otherwise noted.. 
A

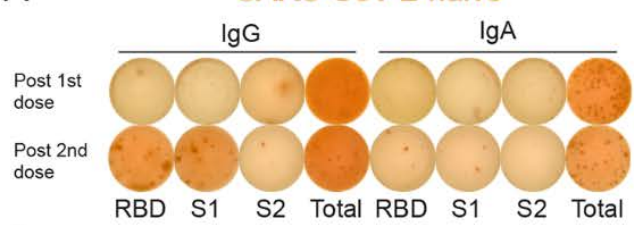

C

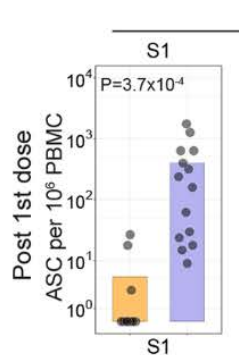

E

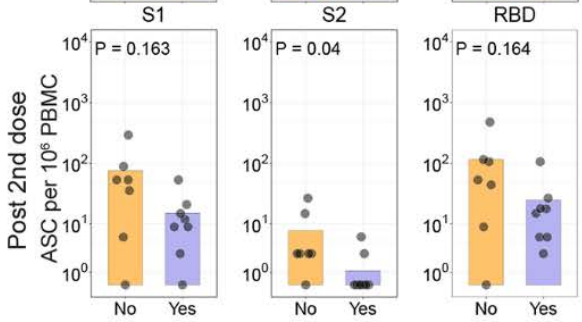

Prior COVID-19?

J

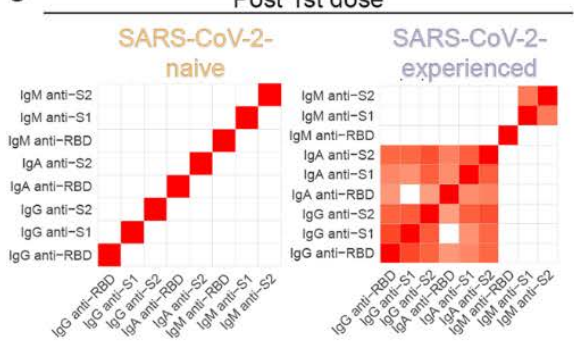
$\lg \mathrm{G}$

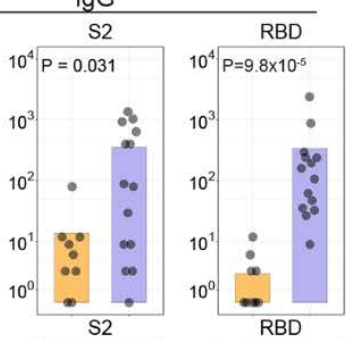

$\mathrm{K}$
B SARS-CoV-2-experienced

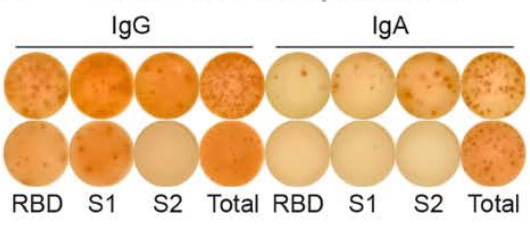

D

$\lg A$

G

SARS-COV-2- SARS-COV-2-
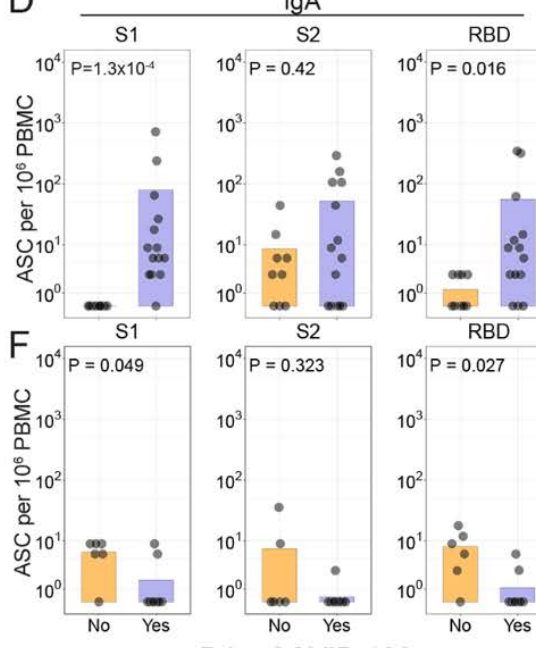

$10^{4} P=0.323$

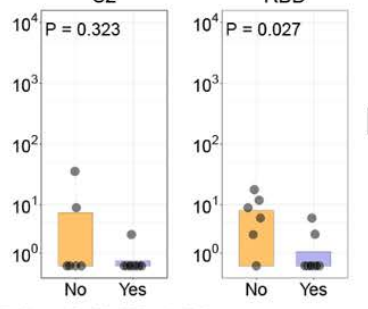

Prior COVID-19?
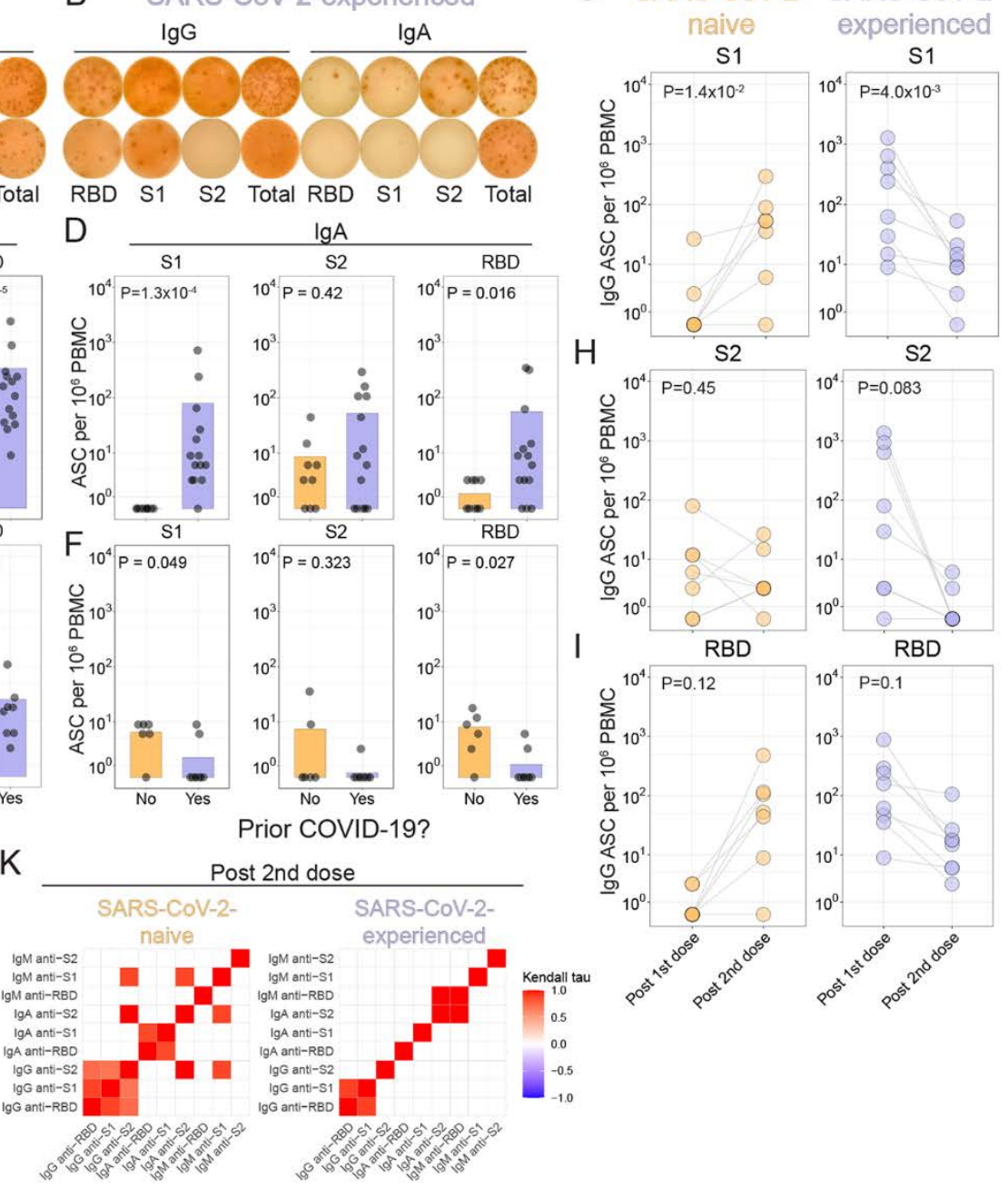

$\mathrm{H}$
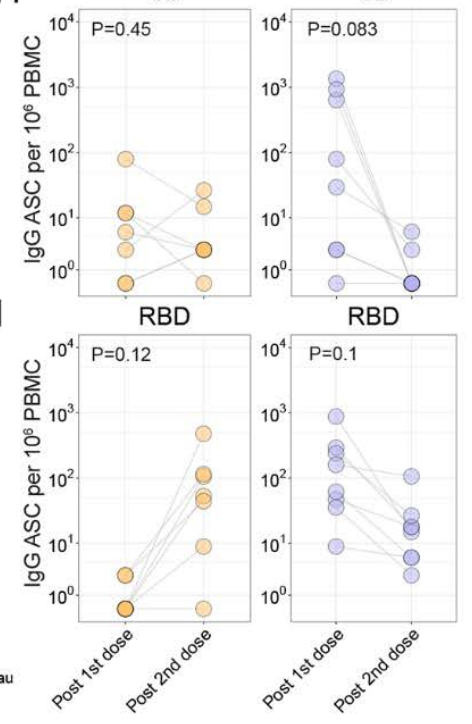

Fig. 4. Few antigen-specific ASCs are induced in circulation after the second vaccine dose in SARSCoV-2-experienced adults. (A and B) Example antibody-secreting cell (ASC) ELISpots for a SARS-CoV2-naive $(A)$ or SARS-CoV-2-experienced $(B)$ adult one week after each dose of vaccine are shown. ( $C$ to F) Summary statistics for ELISpot assays are shown. For each panel, S1 (left), S2 (middle), or RBD (right) antigens for IgG or IgA are represented, at one week after first dose (C and D) for SARS-CoV-2-naive (orange, $n=9$ ) and SARS-CoV-2-experienced (purple, $n=13$ ) participants or one week after second dose ( $\mathrm{E}$ and $\mathrm{F}$ ) for SARS-CoV-2-naive (orange, $\mathrm{n}=6$ ) and SARS-CoV-2-experienced (purple, $\mathrm{n}=8$ ) participants. Nominal $P$ values were calculated by Wilcoxon tests. (G to I) ELISpot results for SARS-CoV-2-naive (left, $\mathrm{n}=7$ ) or SARS-CoV-2-experienced (right, $\mathrm{n}=8$ ) adults are shown for S1 (G), S2 (H), or RBD (I). Connected lines indicate repeated measurements from the same participants. Nominal $P$ values from paired $t$ tests are presented. ( $\mathrm{J}$ and $\mathrm{K}$ ) Kendall correlations are shown for ELISpot results one week after the first vaccination $(J)$ or one week after the second vaccination (K) for SARS-CoV-2-naive $(n=9)$ and SARS-CoV2 -experienced $(n=13)$ participants. Correlations shown for comparisons with nominal $P$ values $<0.05$. 
A

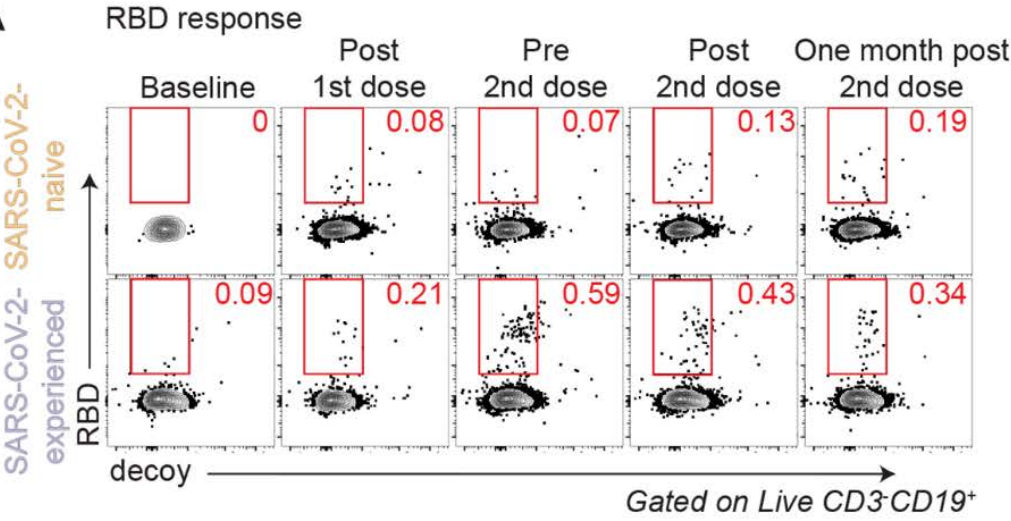

C

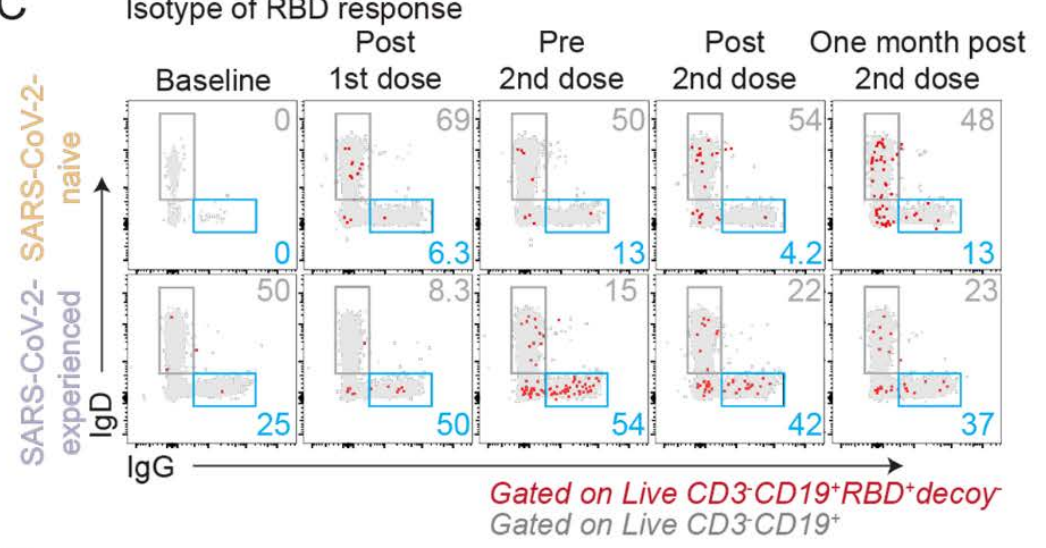

E $\quad$ CD71 expression of $\mathrm{RBD}^{+} \mathrm{B}$ cells

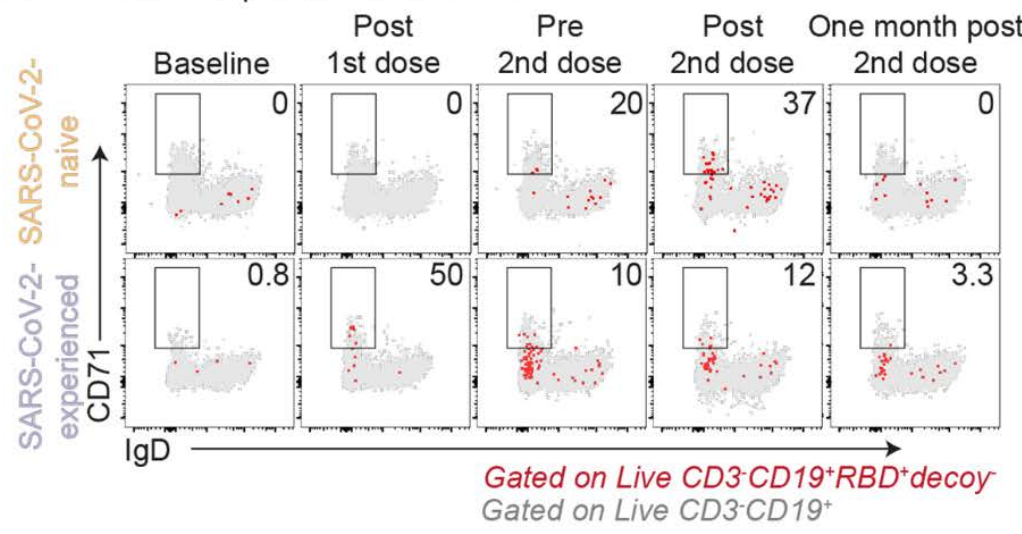

B

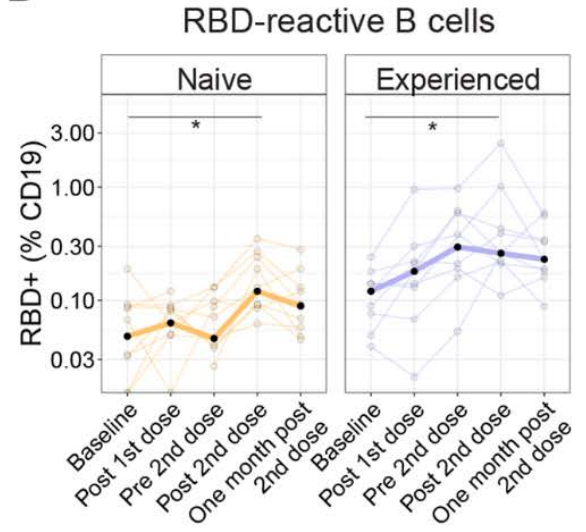

D

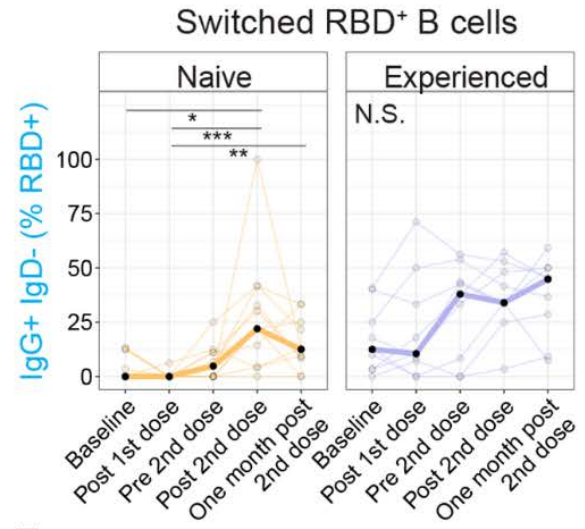

$\mathrm{F}$

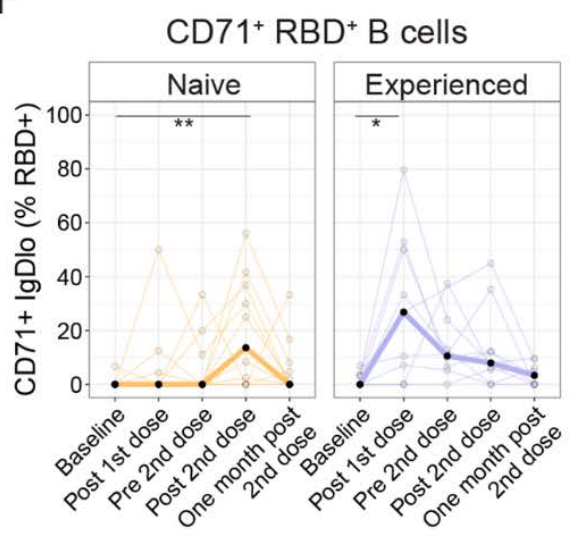

Fig. 5. Antigen-specific $B$ cells are induced by immunization. Recombinant biotinylated RBD was tetramerized and used to detect RBD-reactive $B$ cells by flow cytometry. For all plots, ${ }^{*} P<0.05$, ${ }^{* *} P<0.01$, and ${ }^{* * *} P<0.001$ by Dunn's post-test. (A and B) Example flow cytometry gating for RBD ${ }^{+}$decoy $\mathrm{CD}^{-}{ }^{+} \mathrm{B}$ cells (A) and summary plots (B) are shown for SARS-CoV-2-naive (orange, $n=11$ ) and SARS-CoV-2-experienced (purple, $n=9$ ) participants. Red numbers indicate frequency. Thick lines represent median of values. (C) RBD+ $B$ cell expression of $\operatorname{lgD}$ and $\lg G$ is shown, with $\mathrm{RBD}^{+}$decoy $\mathrm{B}$ cells (red) overlaid on all $\mathrm{CD} 19^{+} \mathrm{B}$ cells (gray). Blue and gray numbers indicate frequency. (D) Summary plots for data presented in (C) are shown for SARS-CoV-2-naive (orange, $n=11$ ) and SARS-CoV-2-experienced (purple, $n=9$ ) participants. Thick lines represent median of values. (E) RBD ${ }^{+} B$ cell expression of IgD and CD71 is shown for RBD ${ }^{+} B$ cells (red) overlaid on all CD19+ B cells (gray). Black numbers indicate frequency. (F) Summary plots for data presented in (E) are shown for SARS-CoV-2-naive (orange, $n=11$ ) and SARS-CoV-2-experienced (purple, $n=9$ ) participants. Thick lines represent median of values. 
A

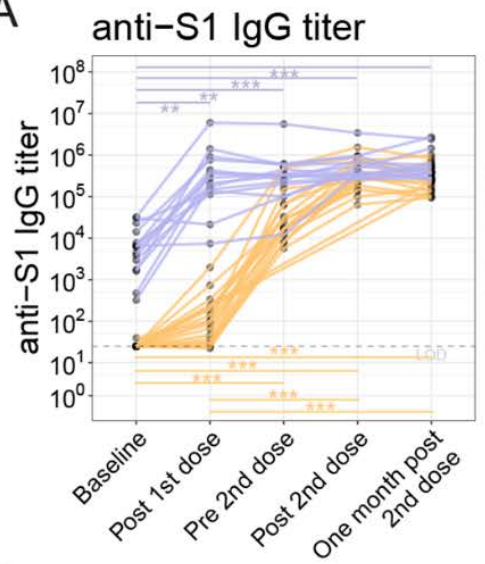

D

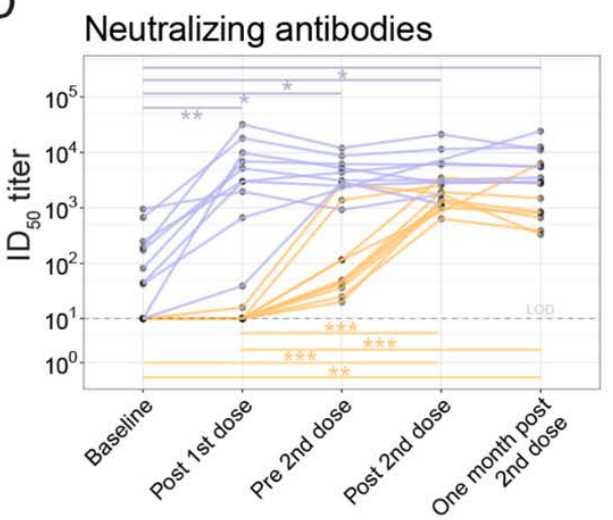

B

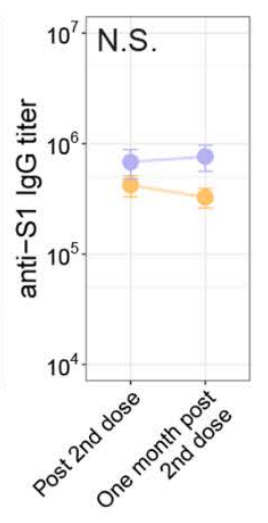

B anti-S1 IgA titer

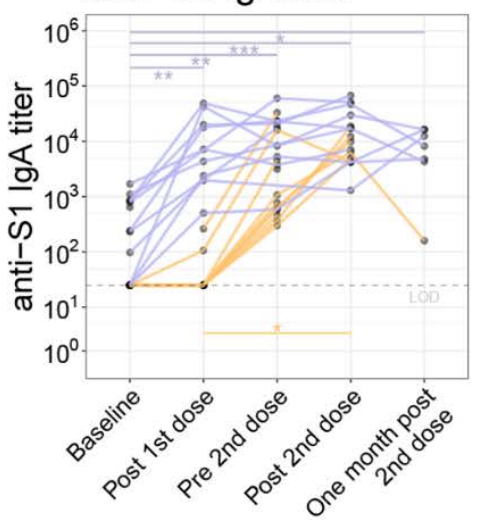

E
E anti-S1 lgG Avidity

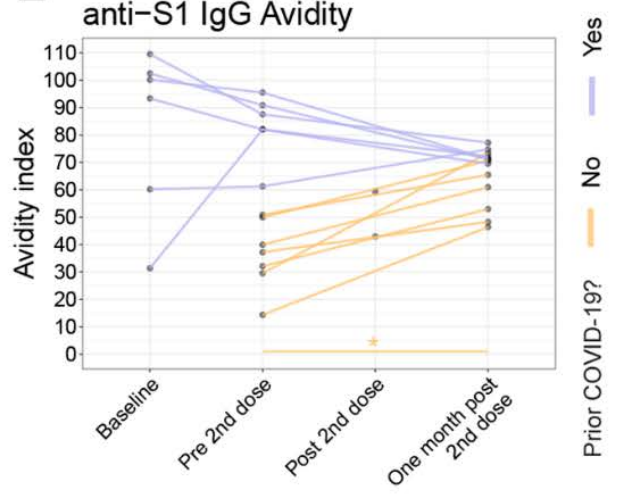

C Plasma neutralization SARS-CoV-2-naive Post1 Pre2 Post2

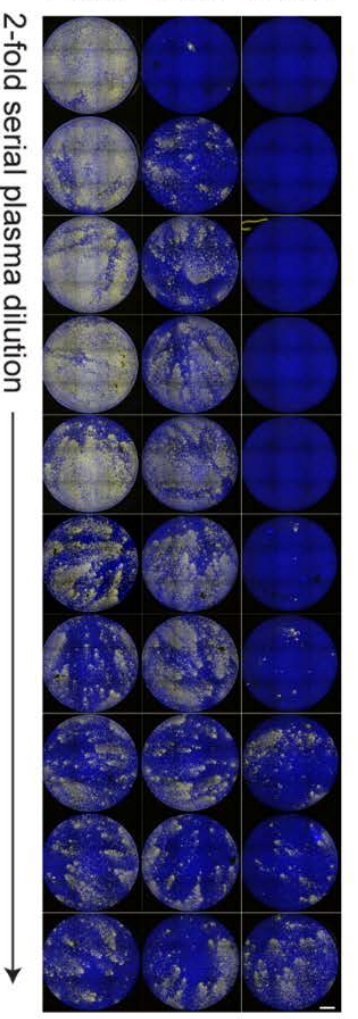

Fig. 6. Antibody responses differ based on prior history of COVID-19. (A) Anti-S1 IgG antibody titers were assessed for SARS-CoV-2 naive (orange, $n=21$ ) and SARS-CoV-2-experienced (purple, $n=15$ ) adults (left) with connected lines indicating repeated measurements of the participants over time. At right, anti-S1 IgG antibody titer summarized at the Post 2nd dose and One month post 2nd dose time points for each cohort. Symbols indicate mean, and error bars indicate standard error. LOD indicates limit of detection. (B) Anti-S1 IgA antibody titers are shown for SARS-CoV-2-naive (orange, $\mathrm{n}=10$ ) and SARS-CoV-2-experienced (purple, $\mathrm{n}=13$ ) participants. (C) Plasma neutralizing antibody titers were assessed with an in vitro microneutralization assay using SARS-CoV2 live virus. A representative serial dilution series is shown for one participant's plasma at the Post 1st dose (Post1), Pre 2nd dose (Pre2), and Post 2nd dose (Post2) time points. Scale bar indicates $100 \mu \mathrm{m}$. (D) Neutralizing antibody titers are shown as $\log _{10}$ of half-maximal inhibitory dilution $\left(I_{50}\right)$ for SARS-CoV-2-naive (orange, $n=10$ ) and SARS-CoV-2-experienced (purple, $\mathrm{n}=10$ ) participants. (E) Anti-S1 IgG antibody avidity was assessed using a urea wash ELISA. Data are expressed as a ratio of urea washed-absorbance to unwashed absorbance for SARSCoV-2-naive (orange, $\mathrm{n}=7$ ) and SARS-CoV-2-experienced (purple, $\mathrm{n}=6$ ) participants. For all plots, N.S., not significant, ${ }^{*} P<0.05$, ${ }^{* *} P<0.01$, and ${ }^{* * *} P<0.001$ by Dunn's post-test unless otherwise noted. 